Toxic Substances Hydrology Program

\title{
Effects of a Crude-0il Recovery Remediation System Operated 1999-2003 on Groundwater Plumes and Unsaturated-Zone Vapor Concentrations at a Crude-Oil Spill Site Near Bemidji, Minnesota
}

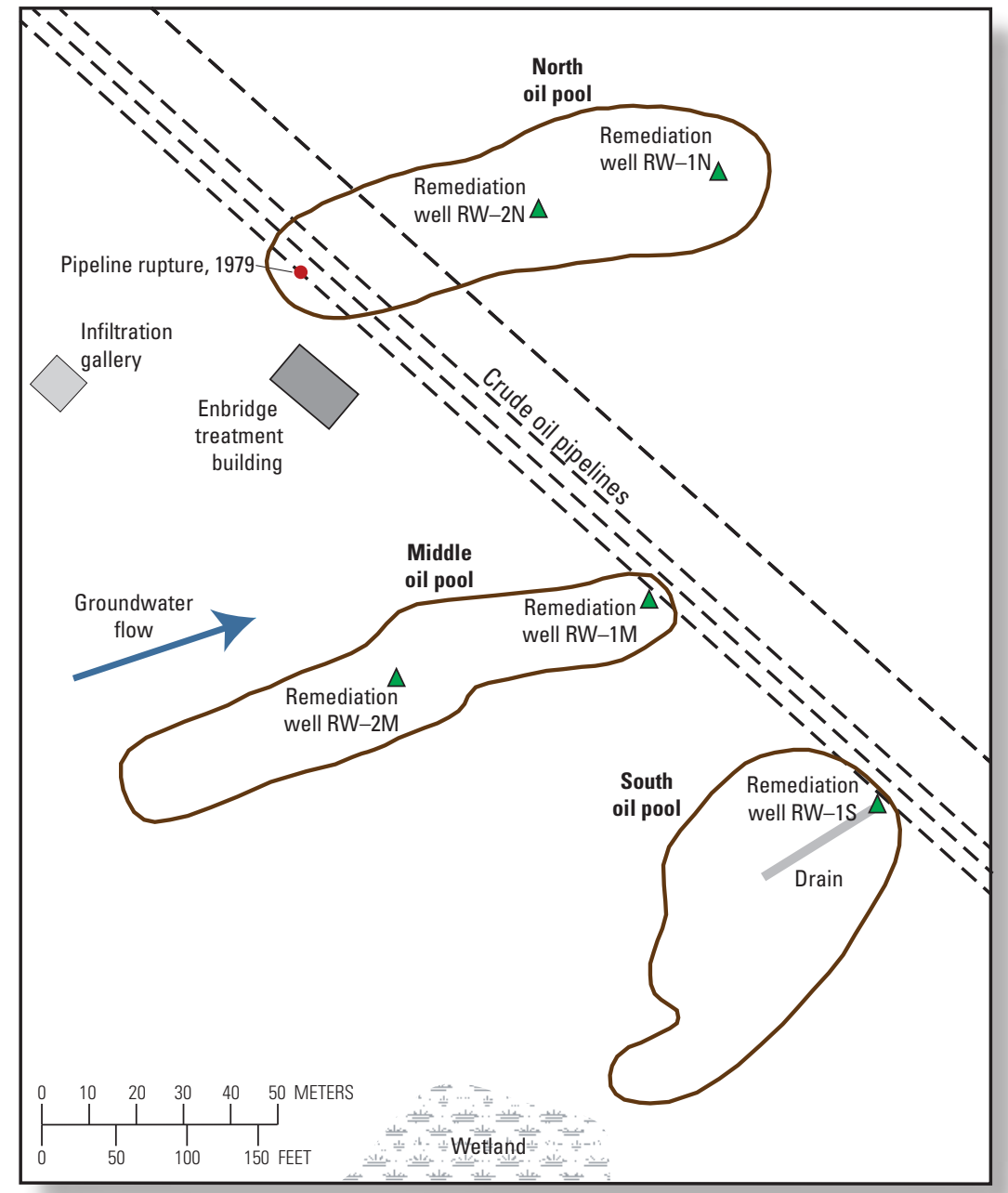

Scientific Investigations Report 2020-5111 
Cover figure: Features associated with the 1999-2003 crude oil remediation at the National Crude Oil Spill Fate and Natural Attenuation Research site near Bemidji, Minnesota. 


\section{Effects of a Crude-0il Recovery Remediation System Operated 1999-2003 on Groundwater Plumes and Unsaturated-Zone Vapor Concentrations at a Crude-Oil Spill Site Near Bemidji, Minnesota}

By Geoffrey N. Delin, William N. Herkelrath, and Jared J. Trost

Toxic Substances Hydrology Program

Scientific Investigations Report 2020-5111 


\title{
U.S. Department of the Interior \\ DAVID BERNHARDT, Secretary
}

\author{
U.S. Geological Survey \\ James F. Reilly II, Director
}

U.S. Geological Survey, Reston, Virginia: 2020

For more information on the USGS - the Federal source for science about the Earth, its natural and living resources, natural hazards, and the environment-visit https://www.usgs.gov or call 1-888-ASK-USGS.

For an overview of USGS information products, including maps, imagery, and publications, visit https://store.usgs.gov/.

Any use of trade, firm, or product names is for descriptive purposes only and does not imply endorsement by the U.S. Government.

Although this information product, for the most part, is in the public domain, it also may contain copyrighted materials as noted in the text. Permission to reproduce copyrighted items must be secured from the copyright owner.

Suggested citation:

Delin, G.N., Herkelrath, W.N., and Trost, J.J., 2020, Effects of a crude-oil recovery remediation system operated 1999-2003 on groundwater plumes and unsaturated-zone vapor concentrations at a crude-oil spill site near Bemidji, Minnesota: U.S. Geological Survey Scientific Investigations Report 2020-5111, 31 p., https://doi.org/10.3133/ sir20205111.

Associated data for this publication:

Trost, J.J., Krall, A.L., Baedecker, M.J., Cozzarelli, I.M., Herkelrath, W.N., Jaeschke, J.B., Delin, G.N., Berg, A.M., and Bekins, B.A., 2020, Data sets from the National Crude Oil Spill Fate and Natural Attenuation Research site near Bemidji, Minnesota, USA (ver. 3.0, April 2020): U.S. Geological Survey data release, https://doi.org/10.5066/P9FJ8I0P.

U.S. Geological Survey, 2020, USGS water data for the Nation: U.S. Geological Survey National Water Information System database, https://doi.org/10.5066/F7P55KJN.

ISSN 2328-0328 (online) 


\section{Acknowledgments}

The efforts of numerous researchers from numerous universities are appreciated for assisting with technical consultation and various analyses and data collection associated with this report. The authors acknowledge the collaboration of Enbridge Inc., Beltrami County, and the Minnesota Pollution Control Agency in this research.

We thank the numerous U.S. Geological Survey (USGS) employees who contributed their assistance with technical consultation and various analyses and data collection associated with this report. We thank in particular our USGS colleagues in the Upper Midwest Water Science Center in Minnesota for sample collection and analytical support. The authors thank USGS technical reviewers Ean Warren and Melinda Erickson for providing valuable comments that substantially improved this report. This research was supported primarily through the USGS Toxic Substances Hydrology Program with additional support through the USGS National Research Program. 



\section{Contents}

Acknowledgments ……...................................................................................................................

Abstract

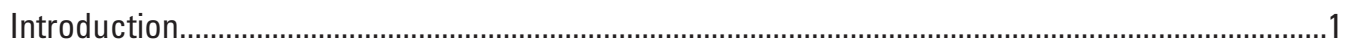

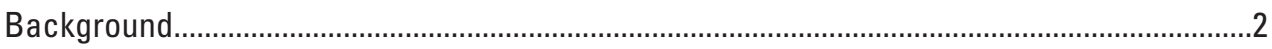

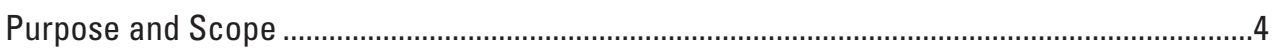

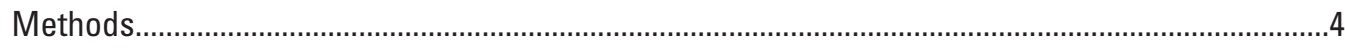

Estimating Initial and Recoverable Oil at the Bemidji Site....................................................

Measuring Oil Thickness ...........................................................................................................

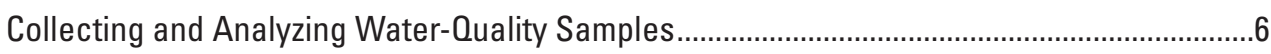

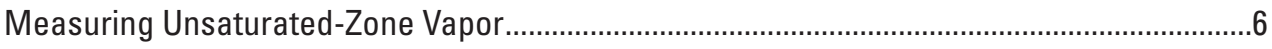

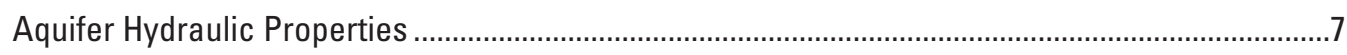

Oil Removed by 1999-2003 Remediation ..........................................................................................

Estimate of Initial Oil at the Bemidji Site, Before Renewed Remediation ...................................7

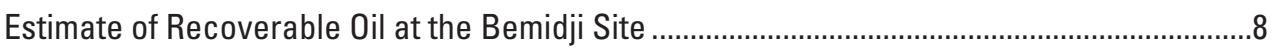

Reported Oil Recovery .................................................................................................

Effects of the Crude-Oil Recovery Remediation System on Groundwater Plumes and

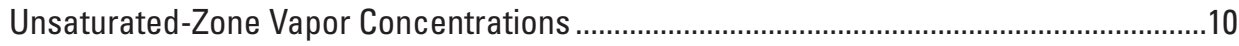

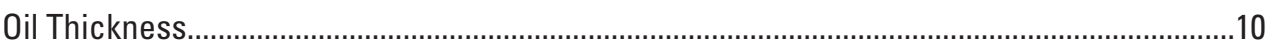

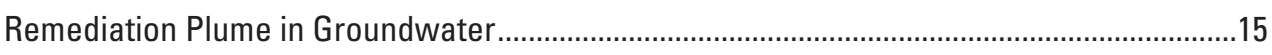

Field Water-Quality Measurements and the Remediation Plume .................................15

Estimates of the Remediation Plume Location ..........................................................18

Benzene, Toluene, Ethylbenzene, and Xylene and the Remediation Plume ...................19

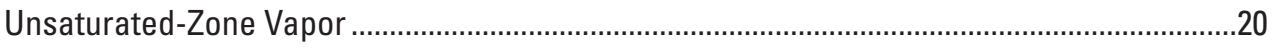

Summary

References Cited

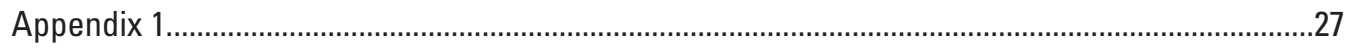

\section{Figures}

1. Map showing observation wells at the National Crude Oil Spill Fate and Natural Attenuation Research site near Bemidji, Minnesota.............................................................

2. Conceptual diagram showing the crude-oil-recovery system for the renewed remediation at the Bemidji, Minnesota, site, 1999-2003 ..................................................

3. Cross section showing vapor well sampling port locations at the Bemidji, Minnesota, north oil pool.

4. Maps showing estimated total volume of crude oil per unit cross section at the north oil pool..

5. Graph showing oil-recovery rates and cumulative oil recovered at the Bemidji, Minnesota, site, 1999-2003

6. Graph showing oil thickness and estimated water-table elevation for well 315 at the north oil pool of the Bemidji, Minnesota, site, 1996-2008

7. Graph showing oil thickness and estimated water-table elevation for well 980 at the south oil pool at the Bemidji, Minnesota, site, 1999-2008 . 
8. Graphs showing relation between estimated water-table elevation and oil thickness in wells at the Bemidji, Minnesota, north oil pool

9. Diagrams showing plumes in the saturated zone at the Bemidji site.

10. Graphs showing concentrations of dissolved oxygen, $\mathrm{pH}$, specific conductance, and temperature for selected wells from 1998 through 2010

11. Graphs showing time series of methane, carbon dioxide, nitrogen, and oxygen vapor concentrations during 1997-2010 for selected vapor sampling ports at the Bemidji, Minnesota, north oil pool, in percentage by volume

\section{Tables}

1. Estimates of initial and recoverable volumes of crude oil at the Bemidji, Minnesota, north and south oil pools.

2. Total crude-oil recovery, in liters, reported by the Natural Resources

Engineering Company (2008).

3. Approximate distance downgradient from the infiltration gallery for the natural attenuation plume compared to estimates for the remediation plume based on observed dissolved oxygen measurements, the maximum observed velocity of 0.9 meter per day based on first arrival of anoxic water 160 meters downgradient from the infiltration gallery, and the average velocity of 0.3 meter per day based on all dissolved oxygen first-arrival data

\section{Conversion Factors}

International System of Units to U.S. customary units

\begin{tabular}{|c|c|c|}
\hline Multiply & By & To obtain \\
\hline \multicolumn{3}{|c|}{ Length } \\
\hline centimeter $(\mathrm{cm})$ & 0.3937 & inch (in.) \\
\hline meter $(\mathrm{m})$ & 3.281 & foot $(\mathrm{ft})$ \\
\hline meter $(\mathrm{m})$ & 1.094 & yard (yd) \\
\hline kilometer (km) & 0.6214 & mile (mi) \\
\hline \multicolumn{3}{|c|}{ Area } \\
\hline square meter $\left(\mathrm{m}^{2}\right)$ & 0.0002471 & acre \\
\hline square meter $\left(\mathrm{m}^{2}\right)$ & 10.76 & square foot $\left(\mathrm{ft}^{2}\right)$ \\
\hline \multicolumn{3}{|c|}{ Volume } \\
\hline milliliter $(\mathrm{mL})$ & 0.033814 & ounce, fluid (fl. oz) \\
\hline liter (L) & 33.81402 & ounce, fluid (fl. oz) \\
\hline liter (L) & 2.113 & $\operatorname{pint}(\mathrm{pt})$ \\
\hline liter (L) & 1.057 & quart (qt) \\
\hline liter (L) & 0.2642 & gallon (gal) \\
\hline liter (L) & 61.02 & cubic inch (in $\left.{ }^{3}\right)$ \\
\hline \multicolumn{3}{|c|}{ Flow rate } \\
\hline cubic meter per year $\left(\mathrm{m}^{3} / \mathrm{yr}\right)$ & 0.000811 & acre-foot per year (acre-ft/yr) \\
\hline meter per day $(\mathrm{m} / \mathrm{d})$ & 3.281 & foot per day (ft/d) \\
\hline meter per year $(\mathrm{m} / \mathrm{yr})$ & 3.281 & foot per year $\mathrm{ft} / \mathrm{yr}$ ) \\
\hline
\end{tabular}




\begin{tabular}{lll}
\hline \multicolumn{1}{c}{ Multiply } & \multicolumn{1}{c}{ By } & \multicolumn{1}{c}{ To obtain } \\
\hline \multicolumn{3}{c}{ Flow rate-Continued } \\
\hline liter per minute $(\mathrm{L} / \mathrm{min})$ & 0.264172 & gallon per minute $(\mathrm{gal} / \mathrm{min})$ \\
liter per day $(\mathrm{L} / \mathrm{d})$ & 0.264172 & gallon per day $(\mathrm{gal} / \mathrm{d})$ \\
\hline \multicolumn{2}{c}{ Transmissivity } & \\
\hline meter squared per second $\left(\mathrm{m}^{2} / \mathrm{s}\right)$ & 10.76 & foot squared $\mathrm{per}$ second $\left(\mathrm{ft}^{2} / \mathrm{s}\right)$ \\
\hline
\end{tabular}

U.S. customary units to International System of Units

\begin{tabular}{|c|c|c|}
\hline Multiply & By & To obtain \\
\hline \multicolumn{3}{|c|}{ Length } \\
\hline mile (mi) & 1.609 & kilometer $(\mathrm{km})$ \\
\hline
\end{tabular}

Temperature in degrees Celsius $\left({ }^{\circ} \mathrm{C}\right)$ may be converted to degrees Fahrenheit $\left({ }^{\circ} \mathrm{F}\right)$ as follows:

$$
{ }^{\circ} \mathrm{F}=\left(1.8 x^{\circ} \mathrm{C}\right)+32
$$

\section{Datum}

Vertical coordinate information is referenced to the North American Vertical Datum of 1988 (NAVD 88).

\section{Supplemental Information}

Specific conductance is given in microsiemens per centimeter at 25 degrees Celsius $\left(\mu \mathrm{S} / \mathrm{cm}\right.$ at $\left.25^{\circ} \mathrm{C}\right)$.

Concentrations of chemical constituents in water are given in either milligrams per liter (mg/L) or micrograms per liter ( $\mu \mathrm{g} / \mathrm{L})$.

\section{Abbreviations}

BTEX benzene, toluene, ethylbenzene, and xylene

GC gas chromatograph

LNAPL light nonaqueous phase liquid

Lo total volume of oil per unit area

$L_{r e c} \quad$ recoverable oil volume per unit area

NREC National Resources Engineering Company

NWIS National Water Information System

PVC polyvinyl chloride

$S_{\text {or }} \quad$ residual oil saturation

USGS U.S. Geological Survey

$V_{\text {rec }} \quad$ recoverable oil volume 



\title{
Effects of a Crude-0il Recovery Remediation System Operated 1999-2003 on Groundwater Plumes and Unsaturated-Zone Vapor Concentrations at a Crude-Oil Spill Site Near Bemidji, Minnesota
}

\author{
By Geoffrey N. Delin, William N. Herkelrath, and Jared J. Trost
}

\section{Abstract}

A crude-oil spill occurred in 1979 when a pipeline burst near Bemidji, Minnesota. More than 70 percent of the 1.7 million liters of spilled crude oil was removed shortly thereafter. In response to a requirement by the State regulatory agency to remove the remaining crude to a sheen in all wells, in 1998, the pipeline company installed a dual-pump recovery system at the site. This additional remediation from 1999 to 2003 resulted in removal of about 115,000 liters of crude oil, representing between 36 and 41 percent of the volume of oil (281,000-317,000 liters) estimated to be present in 1998. Effects of the 1999-2003 remediation on groundwater plumes and unsaturated-zone vapor concentrations were evaluated by the U.S. Geological Survey using several methods including measurements of oil thicknesses in wells; field water-quality properties of dissolved oxygen, specific conductance, temperature, and $\mathrm{pH}$ in groundwater; and vapor concentrations of methane, carbon dioxide, nitrogen, and oxygen in the unsaturated zone.

Although the recovery system decreased oil thicknesses near the remediation wells, average oil thicknesses measured in all wells at the site were not reduced substantially. Dissolved oxygen and specific conductance measurements indicate that a secondary plume was created during the remediation, caused by the disposal of pumped water from the remediation wells in an upgradient infiltration gallery. This plume expanded rapidly immediately after the start of the remediation in 1999, resulting in expansion of the anoxic zone of groundwater upgradient and beneath the existing natural attenuation plume. Beginning in 2000-1, for example, specific conductance concentrations noticeably increased in many wells at the north oil pool from about 400 to more than 700 microsiemens per centimeter. The rapid expansion of the anoxic and elevated specific conductance plume indicates that the remediation contributed substantial amounts of biodegradable dissolved organic carbon to groundwater through the infiltration gallery. The trends in vapor data collected before, during, and after the remediation generally support the research hypothesis that crude-oil removal would have an insignificant effect on vapor concentrations in the unsaturated zone. Although there were some small changes in the concentration of methane, carbon dioxide, nitrogen, and oxygen in the unsaturated zone, these changes were not coincident with the beginning or cessation of the remediation and are therefore thought to be the result of other factors affecting biodegradation rates. A decrease in methane concentrations in one representative well, for example, is thought to be the result of reduced rates of biodegradation and methane production from the increasingly more weathered crude oil. Oil-phase recovery at this site was determined to be challenging and resulted in considerable volumes of mobile and entrapped oil remaining in the subsurface despite remediation efforts.

\section{Introduction}

Although the average annual number of crude-oil spills from pipelines decreased from 4.5 to 1.5 releases per year per 1,000 miles (1,600 kilometers [km]) from 1999-2001 to 2007-9, the total amount of oil released annually (about 111,000 liters [L] per 1,600 km) is substantial (Trench, 2011). According to the U.S. Pipeline and Hazardous Materials Safety Administration (https://www.phmsa.dot.gov/, accessed on June 14, 2020), since 1986, there have been nearly 8,000 significant pipeline incidents (nearly 300 per year on average), resulting in more than 500 deaths, more than 2,300 injuries, and nearly $\$ 7$ billion in damage. Since 1986, pipeline accidents have spilled an average of $288,000 \mathrm{~L}$ of hazardous liquids per year. Because the United States has more than $240,000 \mathrm{~km}$ of oil pipeline (Trench, 2003), there is a continued risk to the environment.

Remediation of crude oil is difficult because of sorption and entrapment of the oil in the unsaturated zone. Crude oil retained in the unsaturated zone and associated with the water-table capillary zone is not typically recoverable (Testa and Winegardner, 2000). Spilled crude oil does not float on the water table where it can be easily removed (Farr and others, 
1990; Lenhard and Parker, 1990; Huntley and others, 1994a; Lundegard and Mudford, 1998; Charbeneau, 2000, 2003; American Petroleum Institute, 2004; Charbeneau, 2007). Direct recovery rates from pipeline spills vary widely. Based on case studies from pipeline releases across the country during 1997-2001, and data collected from the U.S. Office of Pipeline Safety, an average of 42 percent of the spilled oil was recovered (Trench, 2003). When remediation is attempted, simple and readily available methods are needed to evaluate its effectiveness.

Published, peer-reviewed evaluations of the effects of crude-oil remediation on oil thicknesses; field water-quality properties of dissolved oxygen, specific conductance, temperature, and $\mathrm{pH}$ in groundwater; and vapor concentrations are limited. Most of the case studies of the recovery of light nonaqueous phase liquids (LNAPLs) have been documented in consulting reports (for example, U.S. Environmental Protection Agency, 2005). Evaluation of free-phase recovery of crude oil in Araucaria, Brazil, was documented in a conference proceeding by Caicedo and others (2003). Abdul (1992) determined that LNAPL thicknesses did not vary significantly within 1 meter $(\mathrm{m})$ of a dual-pump remediation well during an 829-day period when the remediation was monitored. On the other hand, a study by the U.S. Environmental Protection Agency (2005) determined that LNAPL remediation reduced crude-oil thicknesses by as much as 83 percent at some spill sites. None of the previously documented remediation studies, however, provided a long-term (20 or more year) evaluation of crude-oil remediation performances.

A long-term (20+ year), interdisciplinary research project was established by the U.S. Geological Survey (USGS) at a site near Bemidji, Minnesota, in 1983 that provides for long-term evaluation of hydrocarbon fate and remediation performances following a 1979 crude-oil spill when a pipeline burst. More than 70 percent of the 1.7 million L of spilled crude oil was removed shortly thereafter. In response to a requirement in 1997 by the Minnesota Pollution Control Agency to remove the remaining crude to a sheen in all wells, the pipeline company installed a dual-pump recovery system at the site in 1998. This additional remediation from 1999 to 2003 resulted in removal of about 115,000 L of crude oil, representing between 36 and 41 percent of the volume of oil (281,000-317,000 L) estimated to be present in 1998. Effects of the 1999-2003 remediation on groundwater plumes were evaluated by the USGS using several methods including measurements of oil thicknesses in wells; field water-quality in groundwater; and vapor concentrations of methane, carbon dioxide, nitrogen, and oxygen in the unsaturated zone.

The objective of this study was to test our hypothesis that the renewed remediation would not noticeably change the extent of the oil distribution at the site. This hypothesis resulted in part from an estimate of the remediation efficacy based on oil-saturation measurements made at the site (Herkelrath, 1999). A secondary objective was to test our hypothesis that crude-oil removal from the remediation wells would not change the observed trend in vapor concentrations in the unsaturated zone.

\section{Background}

On August 20, 1979, about $16 \mathrm{~km}$ northwest of Bemidji, Minn., an 86-centimeter $(\mathrm{cm})$ diameter crude-oil pipeline burst along a seam weld, spilling about 1.7 million L of crude oil onto glacial outwash deposits (fig. 1; Pfannkuch, 1979; Hult, 1984; Enbridge Energy, 2008). The oil sprayed over an area of about 6,500 square meters $\left(\mathrm{m}^{2}\right)$ and collected in topographic depressions where crude oil infiltrated through the unsaturated zone to the water table. Three subsurface oil bodies, herein termed the "north, middle, and south oil pools," formed on and adjacent to the water table (fig. 1). The spilled oil was a light, low-sulfur crude with a kinematic viscosity ranging from 1.0 to $2.5 \times 10^{-5}$ square meters per second $\left(\mathrm{m}^{2} / \mathrm{s}\right)$ and a specific gravity ranging from 0.85 to 0.87 (Eganhouse and others, 1993; Landon, 1993; Lundy, 2015). In the local aquifer, groundwater at 20 degrees Celsius $\left({ }^{\circ} \mathrm{C}\right)$ has a kinematic viscosity of $1.0 \times 10^{-6} \mathrm{~m}^{2} / \mathrm{s}$. After repair of the ruptured pipeline, remediation efforts by the pipeline company resulted in an estimated 1.2 million $\mathrm{L}$ of the spilled oil being removed, leaving about $460,000 \mathrm{~L}$ of crude oil in the subsurface (Hult, 1984).

A long-term (20+ year), interdisciplinary research project was established by the USGS at the Bemidji site in 1983 in response to the research and regulatory community's need for in situ field-scale studies of hydrocarbon fate and to complement ongoing experimental and modeling efforts (Delin and others, 1998). Since about 2008, the spill site has been referred to as the "National Crude Oil Spill Fate and Natural Attenuation Research site." Crude oil trapped in the unsaturated zone and near the water table has provided a continuous source of hydrocarbon contamination since the spill occurred in 1979. Research at this site has been oriented toward characterizing and quantifying the physical, chemical, and biological processes controlling the fate of hydrocarbons in the subsurface. Results of this and other site research are summarized in Essaid and others (2011). Much of the research results in this report were presented in Delin and Herkelrath (2014); this report provides additional data and expands the interpretive details, most notably in relation to oil-thickness measurements, field water-quality data of dissolved oxygen, specific conductance, temperature, and $\mathrm{pH}$ in groundwater, and vapor concentrations.

In 1997, the Minnesota Pollution Control Agency required that the pipeline company remove any remaining crude to a sheen in all wells at the Bemidji site. The crudeoil-recovery system (figs. 1 and 2) consisted of five dualpump remediation wells: two at the north oil pool (RW-1N, RW-2N), two at the middle oil pool (RW-1M, RW-2M), and one well connected to a drain tile at the south oil pool (RW-1S) (Natural Resources Engineering Company, 1998). 


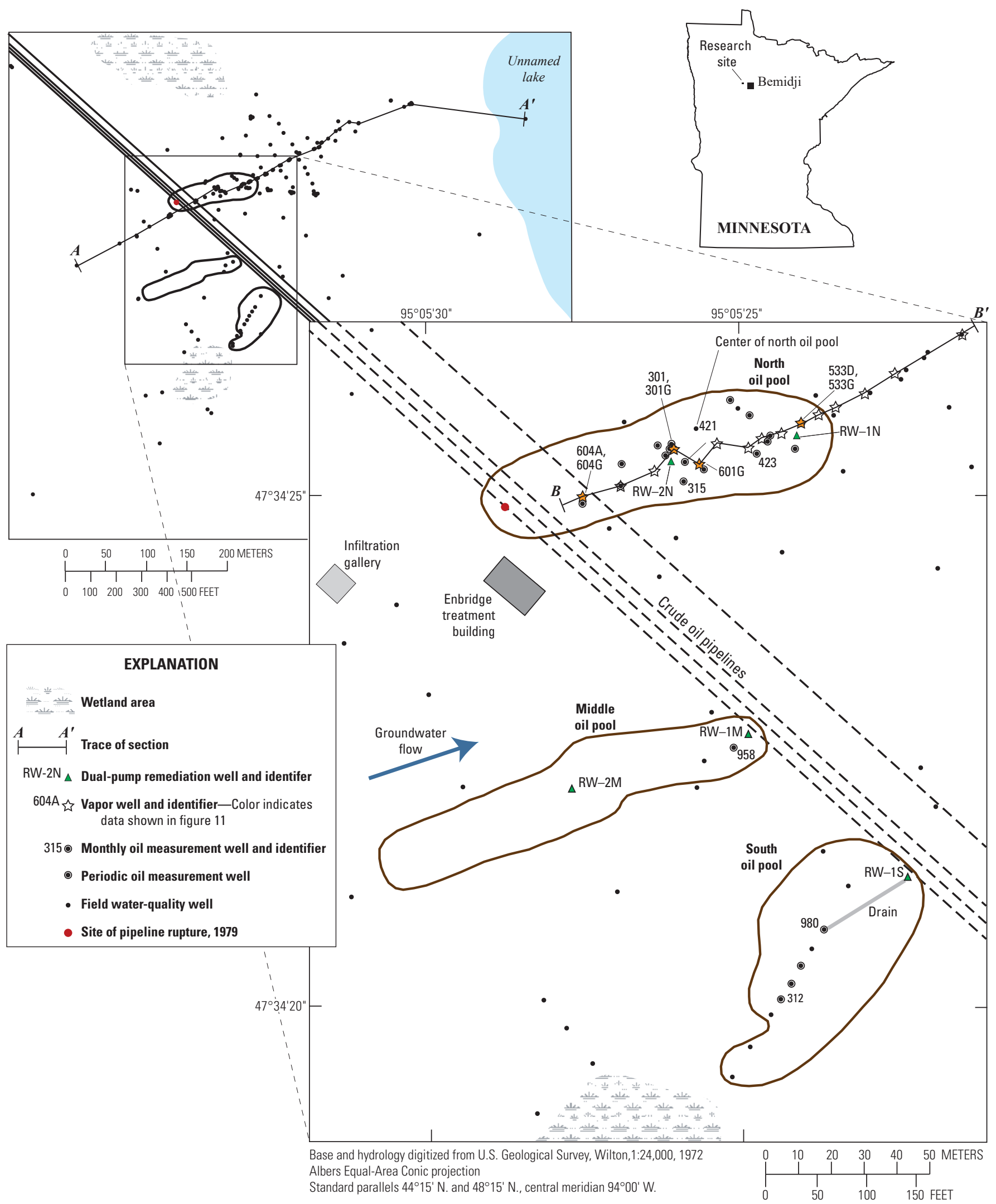

Figure 1. Observation wells at the National Crude Oil Spill Fate and Natural Attenuation Research site near Bemidji, Minnesota. 
The purpose of the drain tile was to funnel the oil toward RW-1S. Each remediation well screen was $3.05 \mathrm{~m}$ long and extended from the water table downward. Pumping with a submersible groundwater pump placed near the bottom of the well created a depression in the water table, which caused crude oil to flow toward the well (fig. 2). The maximum total designed pumping rate for all five wells was 242 liters per minute (L/min) (Natural Resources Engineering Company, 1998, 1999). Crude oil was removed from each well using a pneumatic skimmer pump.

The water-oil mixture from each groundwater pump was discharged into a separator tank in a treatment building (fig. 1) where the oil was pumped to an adjacent storage tank and later removed from the site. Water from the separator tank had no additional treatment and was gravity fed into an infiltration gallery about $40 \mathrm{~m}$ west from the treatment building and upgradient from the north oil pool (fig. 1). The infiltration gallery had a surface area of about $37 \mathrm{~m}^{2}$ and consisted of perforated drain laterals set in gravel beds $2-3 \mathrm{~m}$ below land

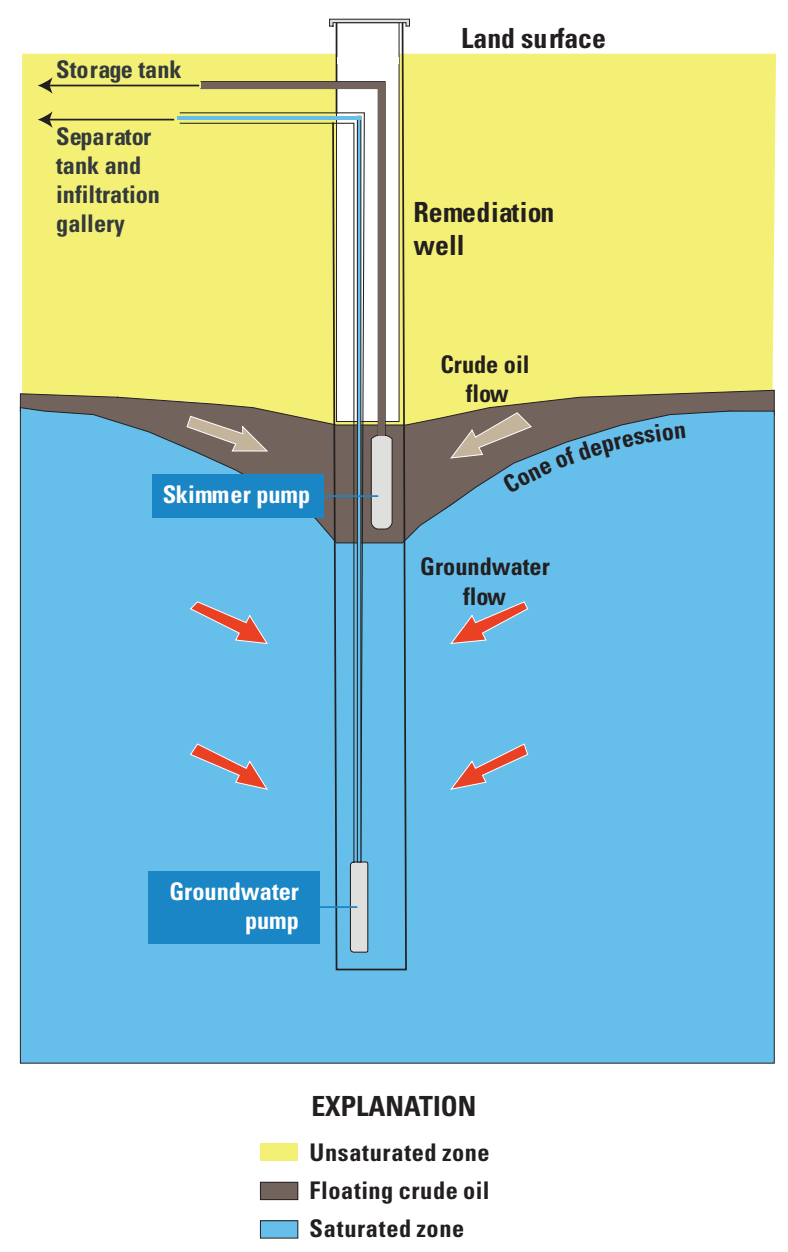

Figure 2. Conceptual diagram of the crude-oil-recovery system for the renewed remediation at the Bemidji, Minnesota, site, 1999-2003. The floating crude-oil zone contained a mixture of crude oil, air, and water in the pore space. surface. Most of the groundwater flowing from the infiltration gallery was intended to be intercepted and withdrawn by remediation wells RW-1N and RW-2N at the north oil pool (Natural Resources Engineering Company, 1998); however, as designed, the remediation system could not intercept all the water that infiltrated through the gallery.

The site is underlain by a glacial aquifer that is $7-20 \mathrm{~m}$ thick, composed of moderately well sorted to poorly sorted sand and gravel with thin interbeds of silt (Franzi, 1988). A regionally extensive till layer underlies the surficial aquifer at depths of 23-28 m. Depth to the water table ranges from $0 \mathrm{~m}$ (near the wetland at the south oil pool, fig. 1) to $9 \mathrm{~m}$ (at the downgradient end of the floating oil at the north oil pool, fig. 1). Typical recharge rates at the site ranged from 0.1 to 0.3 meter per year (m/yr; Delin and Herkelrath, 1999, 2005). The greatest recharge rates occur beneath topographic lows, primarily as a result of accumulation of surface runoff.

\section{Purpose and Scope}

The purpose of this report is to present results of field data collection from 1994 to 2010, spanning a period of time extending from several years before (1994-98) to several years after (2004-10) the 1999-2003 remediation period. The field data that were collected included groundwater levels; oil thickness; water-quality properties including dissolved oxygen, specific conductance, temperature, and $\mathrm{pH}$; and unsaturated-zone soil vapors including methane, carbon dioxide, oxygen, and nitrogen. This report is an expansion of the results presented by Delin and Herkelrath (2014), particularly the description of the field water-quality measurements in groundwater, unsaturated-zone vapor concentrations, and description of the relation between measured oil thickness and estimated water-table elevation.

\section{Methods}

This section describes the methods used for estimating initial and recoverable oil, measuring oil thickness, collecting and analyzing water-quality samples, and measuring unsaturated-zone vapor concentrations used in this study.

\section{Estimating Initial and Recoverable Oil at the Bemidji Site}

The USGS estimate of the volume of oil in the subsurface before the remediation was based on extraction of oil from cores collected from the north and south oil pools in 1998. This part of our research was described in detail by Herkelrath (1999), and an overview is provided in this report. Using methods described in Hess and others (1992) and Murphy and Herkelrath (1996), 17 cores were collected with a freeze shoe apparatus at the north and south oil pools and analyzed to 
measure the vertical distribution of oil, air, and water saturation at the north and south oil pools. Cores were not collected for this study at the middle oil pool. To capture the primary zones of oil saturation, the cores extended from about $30 \mathrm{~cm}$ above the capillary fringe in the unsaturated zone to about $30 \mathrm{~cm}$ below the water table in the saturated zone. The capillary fringe is a zone in which the water and oil saturation rapidly declined above the water table. It was assumed that oil that is more than $1 \mathrm{~m}$ above the water table would not be affected by the remediation (Herkelrath, 1999). This cutoff height above the water table was selected to roughly correspond to the top of the capillary fringe. The total volume of oil per unit area in each core ( $L o$ ) was estimated. Lo has dimensions of length and is equivalent to the length that the oil phase would occupy if the oil were present in a core liner without any sediment. A matrix of estimated values of $L o$ was generated on a uniform grid by interpolating between values of $L o$ measured at the boreholes. Contour maps of the interpolated total volume of oil per unit area at the north oil pool and south oil pool were generated by linear interpolation.

To obtain a first-order estimate of the amount of oil that could be recovered by the remediation, the concept of residual oil saturation $\left(S_{o r}\right)$ was adopted (Dullien, 1992). This concept is commonly used in petroleum engineering. Wherever the oil saturation was initially greater than a residual value of $S_{o r}$, oil was assumed to be removed until the oil saturation was reduced to $S_{o r}$; thus, it was assumed that the maximum oil saturation after remediation would be $S_{o r}$. Wherever the initial oil saturation was less than $S_{o r}$, it was assumed that the oil would be immobile and that the oil saturation would not change during the remediation.

$S_{o r}$ is difficult to estimate and has been determined to depend on many factors that vary widely from site to site; for example, Abdul (1992) reported that $S_{\text {or }}$ ranged from 0.08 to 0.32 ( 8 to 32 percent of the pore space) in small funnels of sand and can be greater in a heterogeneous field environment. At the Bemidji site, one indicator of $S_{o r}$ is the level of oil saturation detected in the unsaturated zone beneath the location where oil infiltration occurred. After 19 years of drainage, the oily sediments detected in the unsaturated zone near the center of the north oil pool had drained to an oil saturation of $0.25 \pm 0.05$. To cover the probable range indicated by these data, oil recovery was calculated assuming $S_{o r}=0.2$ and 0.3 .

The recoverable oil volume $\left(V_{\text {rec }}\right)$ detected in each 75-mm-long core section was used to estimate total oil recovery as follows:

$$
V_{\text {rec }}=V \phi\left(S_{o}-S_{o r}\right)\left(\text { for } S_{o}>S_{o r}\right) \text {, }
$$

where

$V \quad$ is the volume of the core section,

$\phi \quad$ is the porosity of the core section,

$S_{o} \quad$ is the oil saturation in the core section, and

$S_{o r} \quad$ is the assumed residual oil saturation.

$V_{\text {rec }}$ was assumed to be zero if $S_{o}$ is less than $S_{o r}$, as described in detail by Herkelrath (1999).
Individual $V_{\text {rec }}$ values were summed to obtain an estimate of the recoverable oil volume per unit cross section at each borehole location $\left(L_{r e c}\right)$. A contour map of interpolated $L_{\text {rec }}$ values at the north oil pool was developed using $S_{o r}=0.3$. By integrating over the interpolated $L_{\text {rec }}$ matrices, it was estimated that $23,000\left(S_{o r}=0.3\right)$ to $37,000\left(S_{o r}=0.2\right) \mathrm{L}$ of oil could be recovered from the north oil pool. Similar calculations using the south oil pool data indicate that $6,000-16,000 \mathrm{~L}$ of oil could be recovered there. An accurate estimate of recoverable oil volume using the previously mentioned methodology could not be made for the middle oil pool because cores were not collected from that area.

\section{Measuring Oil Thickness}

To evaluate effects of the crude-oil-recovery system, crude-oil thickness was measured in selected wells from 1994 through 2008. Results from previous studies indicate that substantially different volumes of LNAPL may produce the same thickness in an observation well; however, under vertical equilibrium conditions, there should be no exaggeration of LNAPL thickness in a monitoring well compared to the porous media (Abdul and others, 1989; Farr and others, 1990; Lenhard and Parker, 1990; Huntley and others, 1994b). Results from studies at sites where the water-table elevation was fluctuating indicate that oil thickness in observation wells tends to decrease when the water table rises and increase when the water table falls (Hampton and Miller, 1988; Lundy and Gogel, 1988; Kemblowski and Chiang, 1990; Mercer and Cohen, 1990; Marinelli and Durnford, 1996). A rising water table forces oil to flow out of a well bore and into the formation, thereby reducing oil thickness in the well. Conversely, a declining water table allows oil to flow back into the well bore, causing an increase in oil thickness in the well. This flow of oil back into the well depresses the water level, resulting in measured oil thicknesses that may exceed corresponding oil thicknesses in the formation by a factor between 2 and 10 (Mercer and Cohen, 1990).

Oil thicknesses and water levels were measured using an ORS oil-water interface meter in 7 wells monthly and in 16 additional wells once per year (fig. 1; appendix 1). Waterand oil-level data generated during this study are available as a USGS data release (Trost and others, 2020). The waterlevel data are also available through the USGS National Water Information System (NWIS) database (U.S. Geological Survey, 2020) and can be retrieved using the site identifiers listed in appendix 1 . The wells were constructed of $5-\mathrm{cm}-$ diameter polyvinyl chloride (PVC) or galvanized steel, with 0.15-1.5-m-long PVC or stainless-steel screens. The watertable elevation in wells containing crude oil was calculated as the product of oil thickness and a crude-oil specific gravity of 0.855 (Lundy, 2015) plus the elevation of the measured wateroil interface. 


\section{Collecting and Analyzing Water-Quality Samples}

A network of about 100 wells (fig. 1) was sampled each summer from 1998 through 2010 for analyses of selected field water-quality properties that were indicators of effects of the remediation. Specific conductance, $\mathrm{pH}$, dissolved oxygen, and temperature were determined in the field using either a YSI multimeter (model 682-C-M) or a Hydrolab DataSonde 3 or Surveyor 4. Dissolved oxygen and ferrous iron concentrations were measured in the field using CHEMets ${ }^{\circledR}$ Kits (CHEMetrics Inc., Calverton, Virginia). Wells were purged and samples collected in a manner to minimize aeration of the water in the well or the sample during pumping, using positive displacement pumps and gas-impermeable high-density plastic tubing. The measurements were collected in triplicate, and the lowest value measured was reported. These water-quality data can be retrieved from the USGS NWIS database (U.S. Geological Survey, 2020) for the sites listed in appendix 1.

Research completed at this site by Bennett and others (1993) indicates that the combination of dissolved oxygen and specific conductance was a good indicator of biodegradation processes (also National Research Council, 2000). In this study, it was assumed that a dissolved oxygen concentration in groundwater of less than 1.0 milligram per liter $(\mathrm{mg} / \mathrm{L})$ was representative of anoxic conditions in the saturated zone because of microbial biodegradation associated with the crude-oil contamination. By comparison, background dissolved oxygen concentrations typically range from 6 to $7 \mathrm{mg} / \mathrm{L}$ in uncontaminated areas at the site. Similarly, background specific conductance concentrations in groundwater at the site typically range from 300 to 500 microsiemens per centimeter $(\mu \mathrm{S} / \mathrm{cm})$, which increases to between 500 and $900 \mu \mathrm{S} / \mathrm{cm}$ in areas affected by the crude-oil contamination.

Funds were insufficient to collect samples for benzene, toluene, ethylbenzene, and xylenes (BTEX) analysis during the remediation; however, in July 2007, 3.5 years after the remediation had ended, samples were collected from selected wells at the site for BTEX analysis by a separate research study (Amos and others, 2012). Methods used in collecting and analyzing the BTEX samples are included in Amos and others (2012).

\section{Measuring Unsaturated-Zone Vapor}

Vapor samples were collected from the unsaturated zone in the summer during 1997, 1999, and each year from 2001 through 2010. Samples were collected from 15 unsaturatedzone vapor wells, each with multiple vertical sampling ports. The vapor wells are about $10 \mathrm{~m}$ apart horizontally at the north oil pool (figs. 1 and 3). Each vapor well consisted of permanently installed vapor probes generally spaced at $50-100-\mathrm{cm}$ depth intervals in the unsaturated zone, from about $1 \mathrm{~m}$ below land surface to $1 \mathrm{~m}$ above the water table (fig. 3 and appendix 1). Each probe was constructed of 0.16-0.64-cm outside diameter stainless-steel tubing with 1-2-cm-long screened intervals at the bottom. The probes were placed in $10-\mathrm{cm}-$ diameter augered holes, which were then backfilled with native sand and bentonite. Vapor samples were collected in gas-tight glass syringes using a peristaltic pump and analyzed onsite using an SRI ${ }^{\circledR} 8610 \mathrm{C}$ gas chromatograph (GC). The GC was configured using a 1.0-milliliter fixed-loop injection and an internal air compressor. Fixed gas (oxygen, carbon dioxide, methane, and nitrogen) analyses were determined with a thermal conductivity detector and an SRI ${ }^{\circledR}$ CTR -1 double packed column. Calibrations were carried out using gas standards containing mixtures of oxygen, carbon dioxide, methane, and nitrogen. Preliminary vapor transport data collected at the site in 1985 were summarized by Hult and Grabbe (1988). Results from the 1997 and 1999 data collections were summarized by Chaplin and others (2002). The vapor data used in this report are published in the USGS NWIS database (U.S. Geological Survey, 2020) and can be retrieved using the station identifiers in appendix 1 . Well construction and location details are also published in Trost and others (2018). 


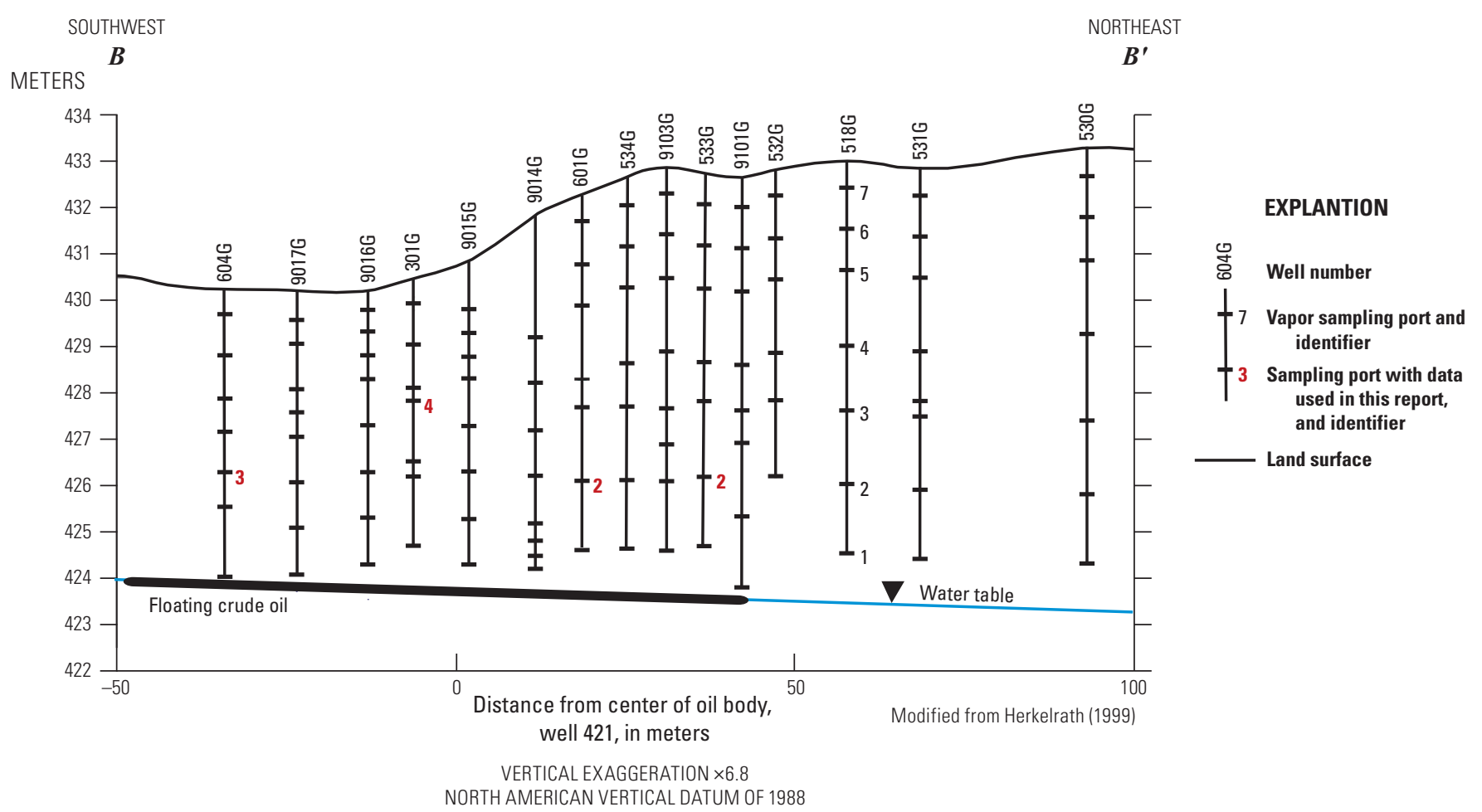

Figure 3. Vapor well sampling port locations at the Bemidji, Minnesota, north oil pool.

\section{Aquifer Hydraulic Properties}

Previous estimates of hydraulic conductivity at the north oil pool were about 8-m/d (Dillard and others, 1997; Essaid and others, 2003). The mean aquifer porosity is 0.38 (Dillard and others, 1997). Based on the previously mentioned estimates of porosity and hydraulic conductivity and an average hydraulic gradient of 0.0035 meter per meter (Essaid and others, 2003, 2011), estimated pore-water velocity at the site is about $0.7 \mathrm{~m} / \mathrm{d}$.

\section{Oil Removed by 1999-2003 Remediation}

The following sections of the report describe the oil removed during remediation completed in 1999-2003 at the Bemidji site. Included in these sections are estimates of initial oil in the subsurface before the remediation began, recoverable oil, and reported oil recovered at the Bemidji site.

\section{Estimate of Initial Oil at the Bemidji Site, Before Renewed Remediation}

By integrating over the interpolated matrices of oil in the unsaturated and saturated zones (fig. 4), the total amount of oil at the north oil pool before the start of the remediation was estimated at $88,000 \mathrm{~L}$ near the water table and 59,000 L in the unsaturated zone (table 1). At the south oil pool, the water table is only about $2 \mathrm{~m}$ below the surface, and almost all the oil is near the water table (table 1); therefore, all the oil at the south oil pool was assumed to be affected by the remediation. It was estimated that the total amount of oil at the north and south oil pools before the start of the remediation was $147,000 \mathrm{~L}$ and $94,000 \mathrm{~L}$, respectively (table 1), for a total of $241,000 \mathrm{~L}$ for both pools. Cores were not collected for this study at the middle oil pool, and thus, an accurate estimate of oil volume in the middle oil pool could not be made.

The Natural Resources Engineering Company (NREC; 1998) estimated oil volumes at the site before the renewed (1999-2003) remediation as the product of measured oil thickness in wells, times the areal extent of each oil pool using push-probe coring, times a published aquifer porosity of 0.25 (Miller, 1984). Cores were collected from 56 push-probe holes, and measurements of oil thicknesses were made in 16 wells on May 15, 1998. The NREC assumed that the thickness of oil in the observation wells equaled the thickness of oil in the aquifer matrix.

The approximate volume of oil in the middle oil pool was estimated in this study by evaluating the relations between the estimates from the NREC (1998) for the north and south oil pools with the corresponding USGS estimates based on cores and applying this relation to the middle oil pool. USGS estimates of oil at the north and south oil pools $(147,000$ and 94,000 L, respectively; table 1) represent 41 percent and 78 percent, respectively, of the NREC estimates for the north and south oil pools. When these ratios are applied to the 
Table 1. Estimates of initial and recoverable volumes of crude oil at the Bemidji, Minnesota, north and south oil pools (modified from Herkelrath, 1999).

[Because the water table is only about 2 meters below the surface at the south oil pool and almost all the oil is near the water table, all the oil at the south oil pool was assumed to be affected by the remediation. USGS, U.S. Geological Survey; NREC, data are from Natural Resources Engineering Company (1998); north, south, middle, oil pool locations; NA, not available]

\begin{tabular}{|c|c|c|c|c|c|c|c|}
\hline \multirow{4}{*}{ Type } & \multicolumn{7}{|c|}{ Assumed residual oil saturation, in thousands of liters } \\
\hline & \multicolumn{4}{|c|}{ USGS } & \multicolumn{3}{|c|}{ NREC } \\
\hline & \multicolumn{2}{|c|}{ North } & \multicolumn{2}{|c|}{ South } & \multirow{2}{*}{$\begin{array}{c}\text { North } \\
0.25\end{array}$} & \multirow{2}{*}{$\begin{array}{c}\text { South } \\
0.25\end{array}$} & \multirow{2}{*}{$\begin{array}{r}\text { Middle } \\
0.25\end{array}$} \\
\hline & 0.3 & 0.2 & 0.3 & 0.2 & & & \\
\hline Initial oil, unsaturated zone & 59 & 59 & 0 & 0 & NA & NA & NA \\
\hline Initial oil, near water table & 88 & 88 & 94 & 94 & NA & NA & NA \\
\hline Total initial volume & 147 & 147 & 94 & 94 & 358 & 121 & 97 \\
\hline Recoverable oil & 23 & 37 & 6 & 16 & NA & NA & NA \\
\hline $\begin{array}{l}\text { Oil remaining in subsurface after } \\
\text { remediation }\end{array}$ & 124 & 110 & 88 & 78 & NA & NA & NA \\
\hline $\begin{array}{l}\text { Recoverable oil volume/total initial } \\
\text { oil volume (in percent) }\end{array}$ & 16 & 25 & 7 & 17 & NA & NA & NA \\
\hline
\end{tabular}

NREC estimate for the middle oil pool of 97,000 L, the USGS estimate of oil volume for the middle oil pool is between about 40,000 and $76,000 \mathrm{~L}$. When these estimates are added to the values in table 1 for the north and south oil pools, the total USGS estimated volume of oil for all three oil pools before the remediation is between 281,000 and $317,000 \mathrm{~L}$.

\section{Estimate of Recoverable Oil at the Bemidji Site}

A substantial fraction of the oil at the north oil pool is above the water table, in the 6-m-thick unsaturated zone (Herkelrath, 1999). Some of the oil in the unsaturated zone is beneath areas where the oil originally infiltrated into the ground and represents a residual saturation of oil that is trapped or flows slowly downward. This oil was hypothesized to be immobile during the remediation.

Results of the residual oil-saturation model indicated that about 110,000-124,000 L of oil would remain at the north oil pool (fig. 3; table 1) and about 78,000-88,000 L would remain at the south oil pool after the renewed oil-recovery remediation (table 1). Thus, the total predicted volume of recoverable oil from the north and south oil pools combined ranged from about 29,000 to $53,000 \mathrm{~L}$ based on residual oil saturations of 0.3 and 0.2 , respectively. The predicted low oil recoveries (16-25 percent at the north oil pool; 7-17 percent at the south oil pool) are in good agreement with other case studies (for example, Abdul, 1992) and from experience within the oil industry (American Petroleum Institute, 2003). These calculations illustrate how difficult it is to remove separate-phase oil from sediments using standard oil-removal technology. If we assume that the recoverable oil from the middle oil pool was in a similar range to that estimated at the north and south oil pools (in other words, 7-25 percent), recoverable oil from the middle oil pool was likely between about 2,800 and 19,000 L. Thus, the total predicted volume of recoverable oil from all three oil pools ranged from about 31,800 to $72,000 \mathrm{~L}$ (or about 10-26 percent of the estimated volume of $281,000-317,000 \mathrm{~L}$ of oil at the north, middle, and south oil pools before the remediation).

\section{Reported Oil Recovery}

The reported oil recovery values are shown in table 2 . The initial oil estimates for the north and south oil pools by the NREC are 243 and 129 percent larger, respectively, than the values estimated in this study (table 1). Oil-recovery rates were greatest during the first year (1999) of the remediation (table 2), with combined rates from all wells as high as about 300 liters per day (fig. 5) (Natural Resources Engineering Company, 2008). This trend in crude-oil recovery is similar to those reported elsewhere in the literature (for example, Abdul, 1992). The observed fluctuations in oil-recovery rates during the remediation, particularly during 1999, were due to problems with the wells and pumps that necessitated temporary shutdown of the oil-recovery system for repair (Natural Resources Engineering Company, 1999). Oil-recovery rates declined in 2000-3, as reflected in the daily oil-recovery and cumulative oil-recovery graphs (fig. 5). Total reported crude-oil recovery is shown in table 2 (Natural Resources Engineering Company, 2008); thus, the renewed remediation from 1999 to 2003 resulted in removal of a total of about 115,000 L of crude oil from the site (table 2; Natural Resources Engineering Company, 2008). This represents 36-41 percent of the USGS total of 281,000-317,000 L estimated to be present at the north, middle, and south oil pools in 1998. The $115,000 \mathrm{~L}$ of oil removed represents only 19 percent of the NREC (1998) estimate of 575,500 L of oil in the subsurface before the start of the remediation. 

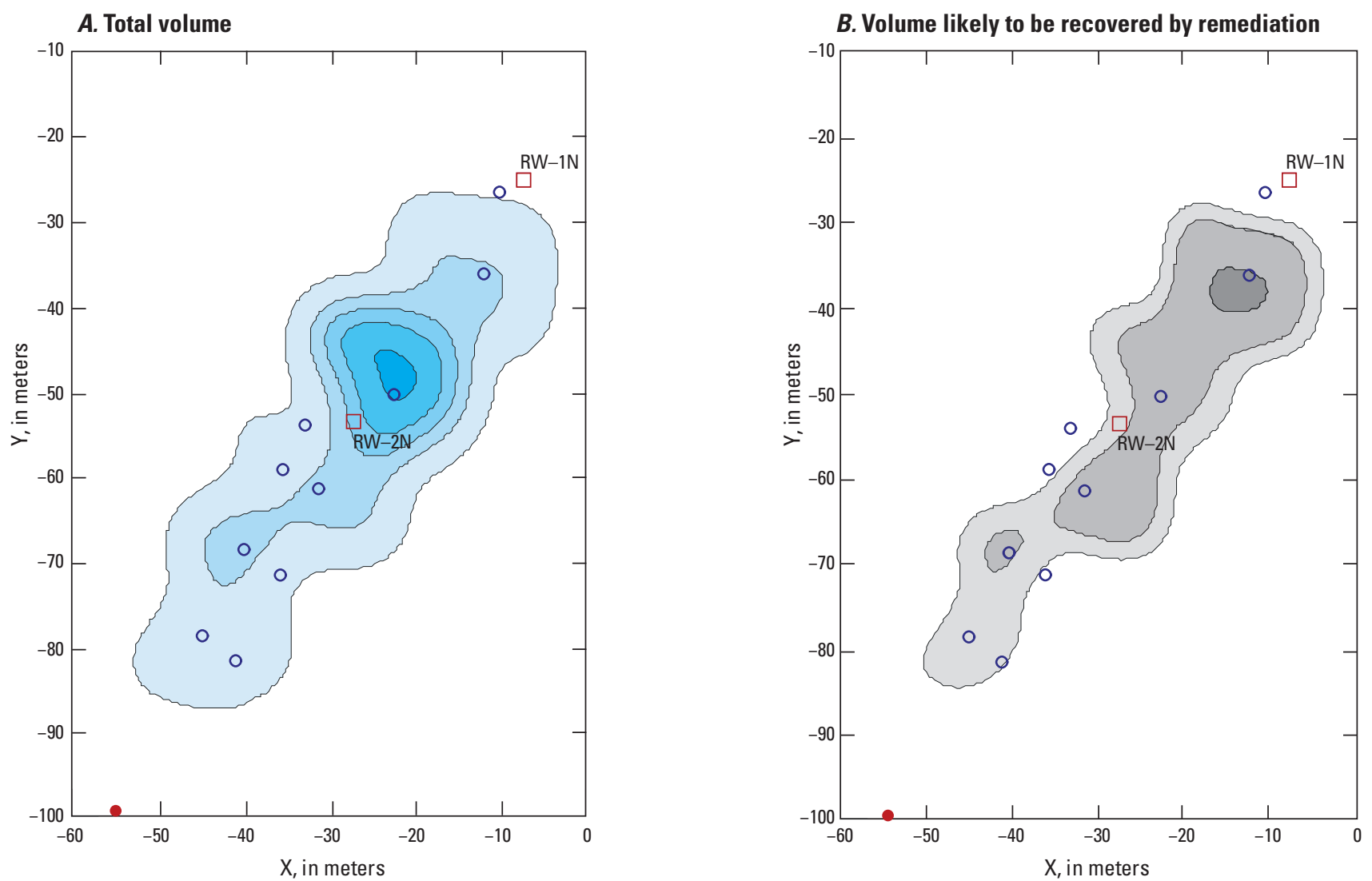

EXPLANATION

[Numbers correspond to estimated crude-oil volume for a residual oil saturation $\left(S_{o r}\right)$ value of 0.3 , in centimeters. The total volume of oil per unit cross-sectional area $(L o)$ in each borehole was estimated. Lo has dimensions of length and is equivalent to the length that the oil phase would occupy if the oil were present in a core liner without any sediment; axis labels use local coordinate system]

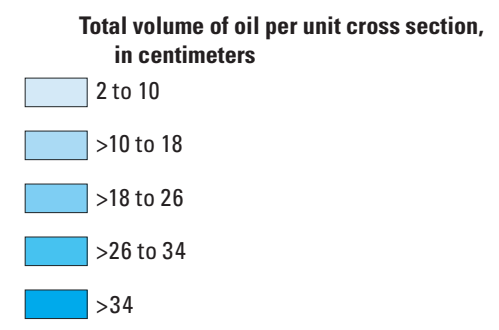

RW-1N $\square$ Oil recovery well and identifier

O Borehole used in this analysis

- Site of pipeline rupture, 1979

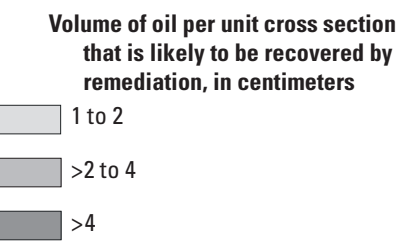

$>4$

Figure 4. Estimated total volume of crude oil per unit cross section at the north oil pool. $A$, oil volume per unit cross sectional area in centimeters in 1998, before the start of the remediation; $B$, oil volume per unit cross sectional area in centimeters that was likely recoverable by the remediation given free oil flow and time. Modified from Herkelrath (1999).

Table 2. Total crude-oil recovery, in liters, reported by the Natural Resources Engineering Company (2008).

\begin{tabular}{lc}
\hline Year & Reported recovery \\
\hline 1999 & 47,300 \\
2000 & 21,100 \\
2001 & 19,900 \\
2002 & 11,000 \\
2003 & 13,700 \\
\hline Total & 115,000 \\
\hline
\end{tabular}

The most likely causes for the differences between USGS's estimated oil-recovery volume (of 31,800-72,000 L) for this study and the reported oil-recovery volume (of 115,000 L, Natural Resources Engineering Company, 2008) are as follows. (1) The USGS estimate of oil volume in place before remediation may be too low. The oil pools may have been more extensive than indicated by our relatively limited coring campaign. (2) The assumed minimum residual oil saturation of $0.2-0.3$ predicted to remain after the remediation may be too high. Unfortunately, we did not have the resources to recore the site after the remediation to measure the remaining oil-saturation distribution. (3) The reported oil-recovery 


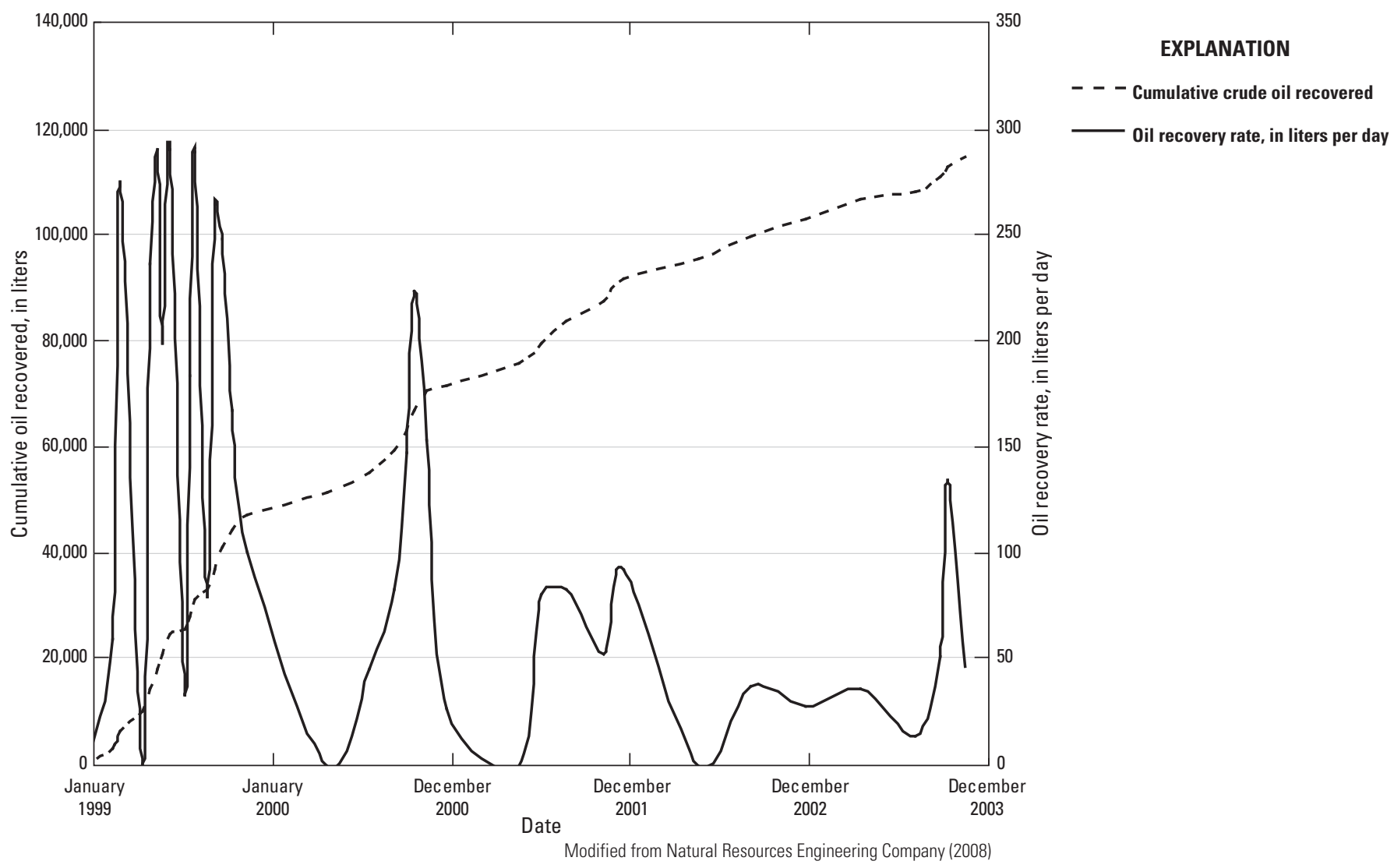

Figure 5. Oil-recovery rates and cumulative oil recovered at the Bemidji, Minnesota, site, 1999-2003.

volume may be too high because of the difficulty of separating oil from water in the field and measuring the recovered oil volume; for example, some volume of water may have been included in the reported recovered oil volume.

\section{Effects of the Crude-Oil Recovery Remediation System on Groundwater Plumes and Unsaturated-Zone Vapor Concentrations}

The following sections of the report describe the effects of the 1999-2003 remediation on groundwater plumes and unsaturated-zone vapor concentrations at the Bemidji site. Included in these sections are descriptions of the oil thicknesses and water levels in wells, the remediation plume in groundwater, and the unsaturated-zone vapor concentrations.

\section{Oil Thickness}

Although the oil-recovery system successfully removed oil from a relatively short radius around each remediation well, the remediation did not appreciably affect overall oil thicknesses measured in wells at the north and south oil pools. Average oil thicknesses in 18 wells at the north oil pool were about $0.7 \mathrm{~m}$ in 1998 before the remediation, varied between about 0.4 and $0.8 \mathrm{~m}$ from 1999 to 2003 during the remediation, and varied between about 0.4 and $0.7 \mathrm{~m}$ from 2004 to 2008 after the remediation ended. Average oil thicknesses in wells at the south oil pool were about $0.5 \mathrm{~m}$ in 1998 before the remediation, varied between about 0.2 and $0.4 \mathrm{~m}$ from 1999 to 2003 during the remediation, and remained constant at about $0.3 \mathrm{~m}$ from 2004 to 2008 after the remediation ended. The lack of change in thickness at the north and south oil pools, as well as seasonal fluctuations in average oil thickness, do not seem to be linked to the remediation but are more likely the result of natural fluctuations of recharge and discharge from the aquifer. Following are results from three observation wells close to the remediation wells as examples of the maximum effects of the remediation.

To evaluate effects of the remediation on oil thicknesses, wells 301A, 315, and 980 were selected for detailed analysis because of their proximity to the remediation wells (fig. 1). In well 315 at the north oil pool, $7.5 \mathrm{~m}$ south of remediation well RW-2N (fig. 1), oil thicknesses fluctuated seasonally with only a slight decrease in thickness during the remediation (fig. 6). Based on the linear regression line through the data, this decrease was consistent with the downward trend in oil thickness from 3 years before to 5 years after the remediation 
ended (1996-2008). The seasonal fluctuations in oil thickness are not linked to the remediation but are the result of natural fluctuations of recharge and discharge from the aquifer.

Of all the wells monitored during the 1999-2003 remediation, the greatest change in oil thickness was observed in well 980 at the south oil pool, $3 \mathrm{~m}$ from the drain attached to remediation well RW-1S (fig. 1). Oil thicknesses in this well decreased to near zero during the remediation but rebounded to preremediation levels within about 1 year after the remediation ended (fig. 7). Well 980 did not have the thickest oil at the site before the remediation; however, its thicknesses were generally less than $0.5 \mathrm{~m}$ compared to thicknesses as great as $1.0 \mathrm{~m}$ in wells such as 315 at the north oil pool.

At well 301A, about $5.0 \mathrm{~m}$ from remediation well RW-2N at the north oil pool (fig. 1), the average oil thicknesses for 1994-98 (before), for 1999-2003 (during), and for 2004-9 (after the remediation) were $0.600 \mathrm{~m}, 0.612 \mathrm{~m}$, and $0.521 \mathrm{~m}$, respectively, indicating a relatively small effect from the remediation. However, figure $8 A$ demonstrates that the oil thicknesses in well 301A were substantially reduced by the remediation when accounting for water-level elevation. The approximate vertical distance between the beforeregression line (black) and the after-regression line (green) is about $0.2-0.4 \mathrm{~m}$. This indicates that at a given water level, the oil thicknesses were about $0.2-0.4 \mathrm{~m}$ less after the remediation compared to before the remediation. Oil viscosities in four wells at the north oil pool increased during the remediation by as much as 20 percent (Lundy, 2015). This increase in oil viscosity may have affected oil thicknesses in wells but an evaluation of this kind was beyond the scope of this study. Although the thicknesses were reduced, the after-remediation

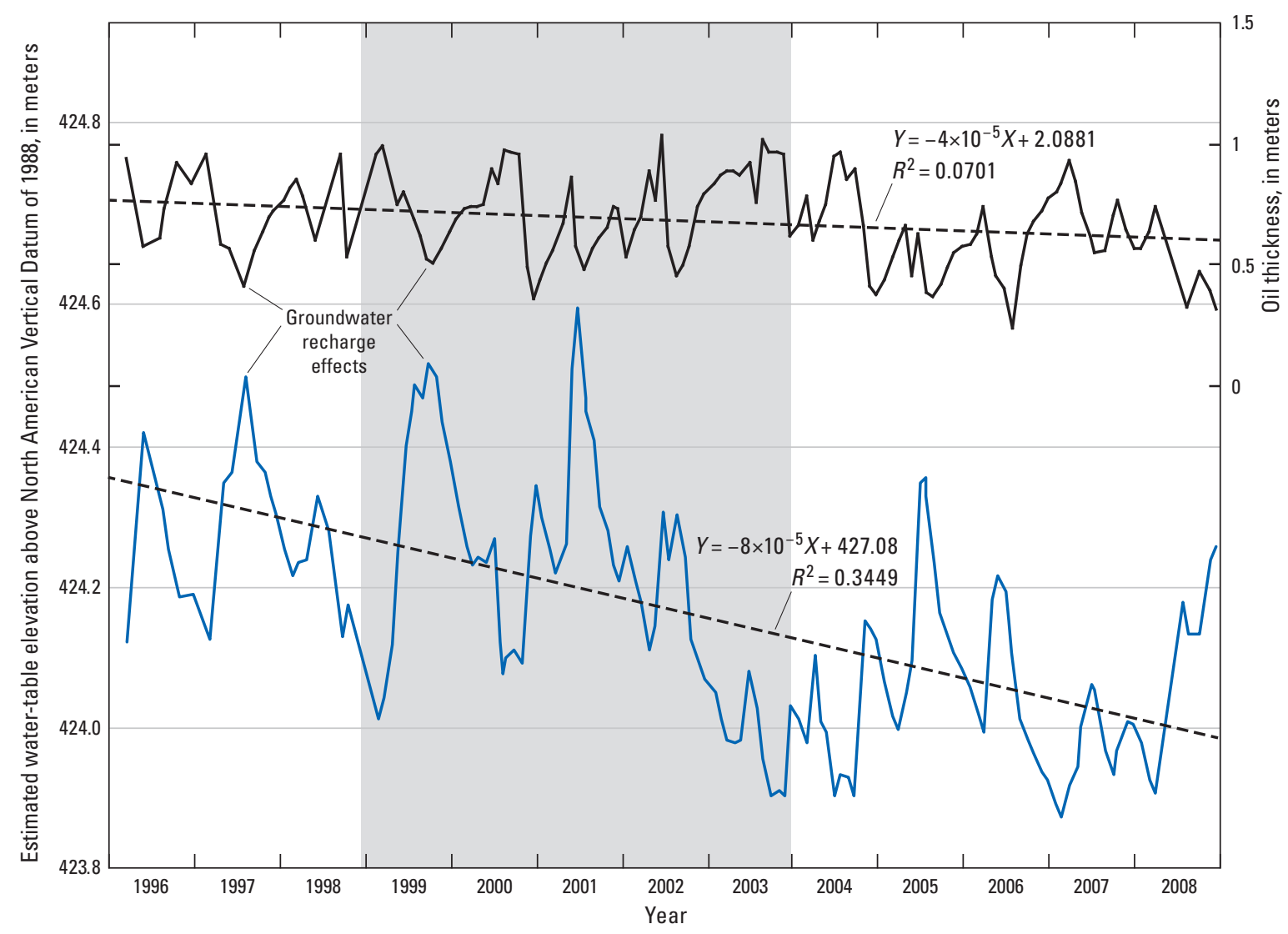

EXPLANATION
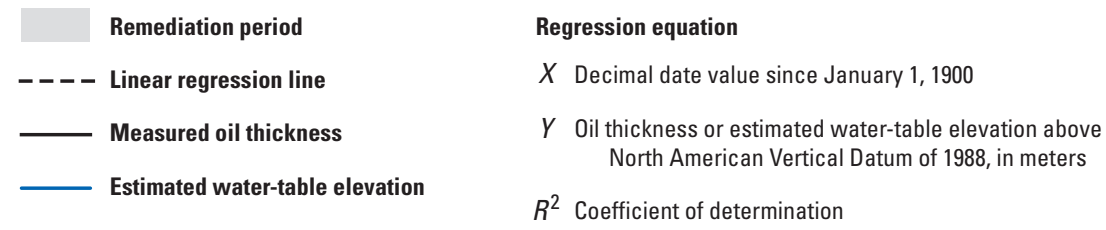

Figure 6. Oil thickness and estimated water-table elevation for well 315 at the north oil pool of the Bemidji, Minnesota, site, $1996-2008$. Effects of groundwater recharge are apparent as rises in the water table coupled with declines in oil thickness, and vice versa. 


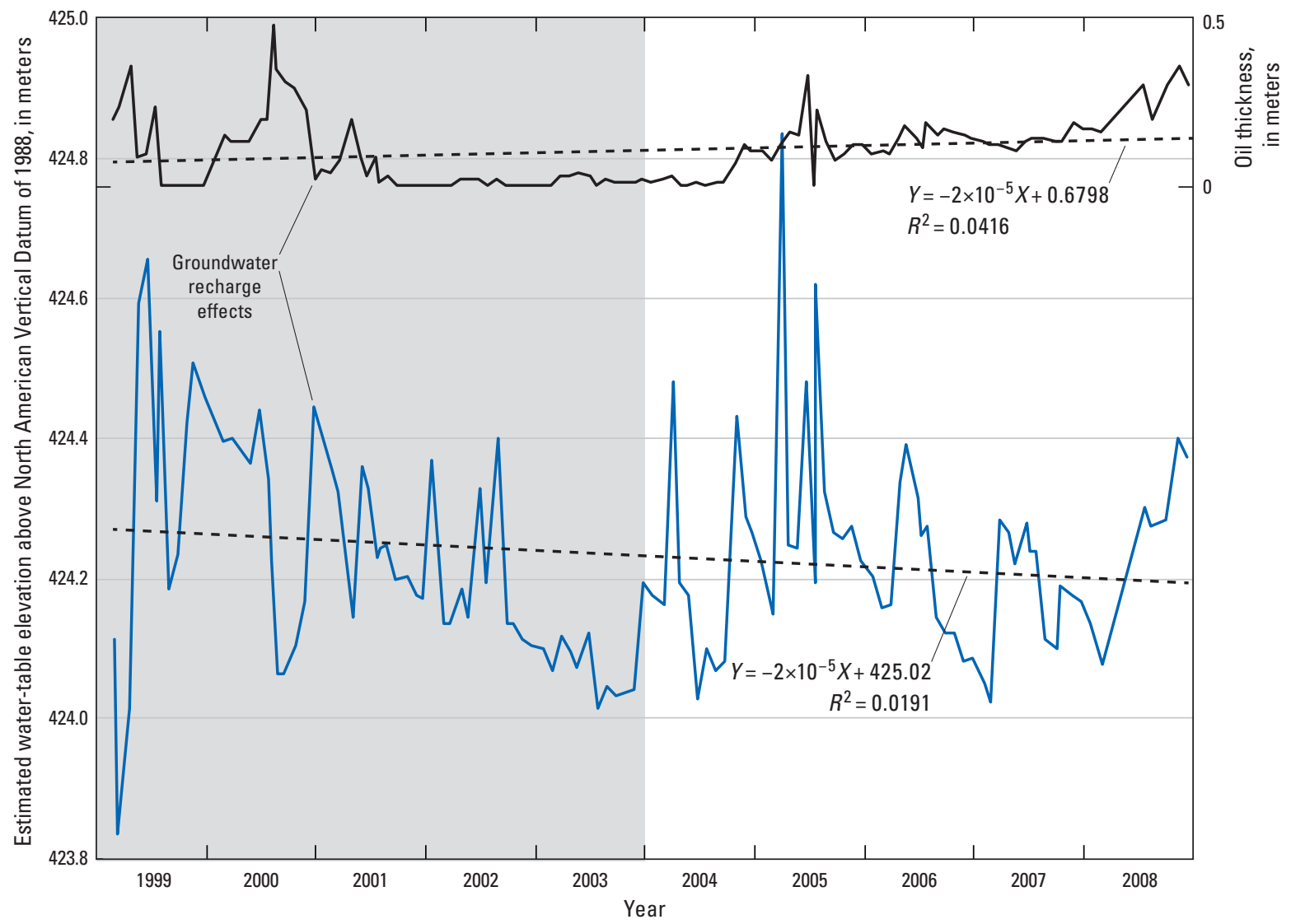

EXPLANATION
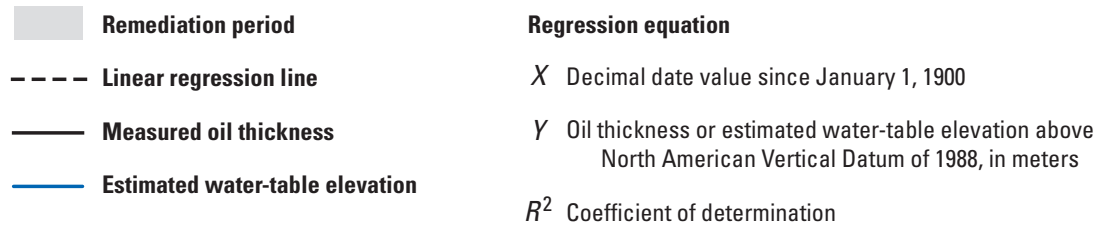

Figure 7. Oil thickness and estimated water-table elevation for well 980 at the south oil pool at the Bemidji, Minnesota, site, 1999-2008. Note that oil thickness was close to zero for about 3 years during the remediation.

data indicate that substantial amounts of oil remained in the subsurface and that the remediation did not achieve the sheen objective.

At well 315 , located $7.5 \mathrm{~m}$ from remediation well RW-2N at the north oil pool (fig. 1), the average oil thicknesses for 1994-98 (before), for 1999-2003 (during), and for 2004-9 (after the remediation) were $0.740 \mathrm{~m}, 0.715 \mathrm{~m}$, and $0.563 \mathrm{~m}$, respectively. Similar to well $301 \mathrm{~A}$, the average oil thicknesses for well 315 indicate a relatively small effect of the remediation effort. The approximate vertical distance between the before-regression line (black) and the afterregression line (green) is about $0.4 \mathrm{~m}$. This indicates that at a given water level, the oil thicknesses were about $0.4 \mathrm{~m}$ less after the remediation compared to before the remediation. Although the thicknesses were reduced, the after-regression data once again indicate that substantial amounts of oil remained in the subsurface and the remediation did not achieve the sheen objective.

At well 980,3.0 m from the drain connected to remediation well RW-1S at the south oil pool (fig. 1), the average oil thicknesses for 1989-96 (before), for 1999-2003 (during), and for 2004-9 (after the remediation) were $0.780 \mathrm{~m}, 0.081 \mathrm{~m}$, and $0.130 \mathrm{~m}$, respectively. Fewer oil-thickness measurements were available for well 980 before the start of the remediation and the period during which the measurements were made was slightly earlier compared to the measurements for wells 301A and 315 (fig. 8). Comparison of the oil-thickness measurements at wells 980,301A, and 315 for the same slightly earlier period, however, indicate that the data at well 980 are nevertheless representative of the preremediation conditions for 1994-98. The data in figure $8 C$ indicate a relatively large 


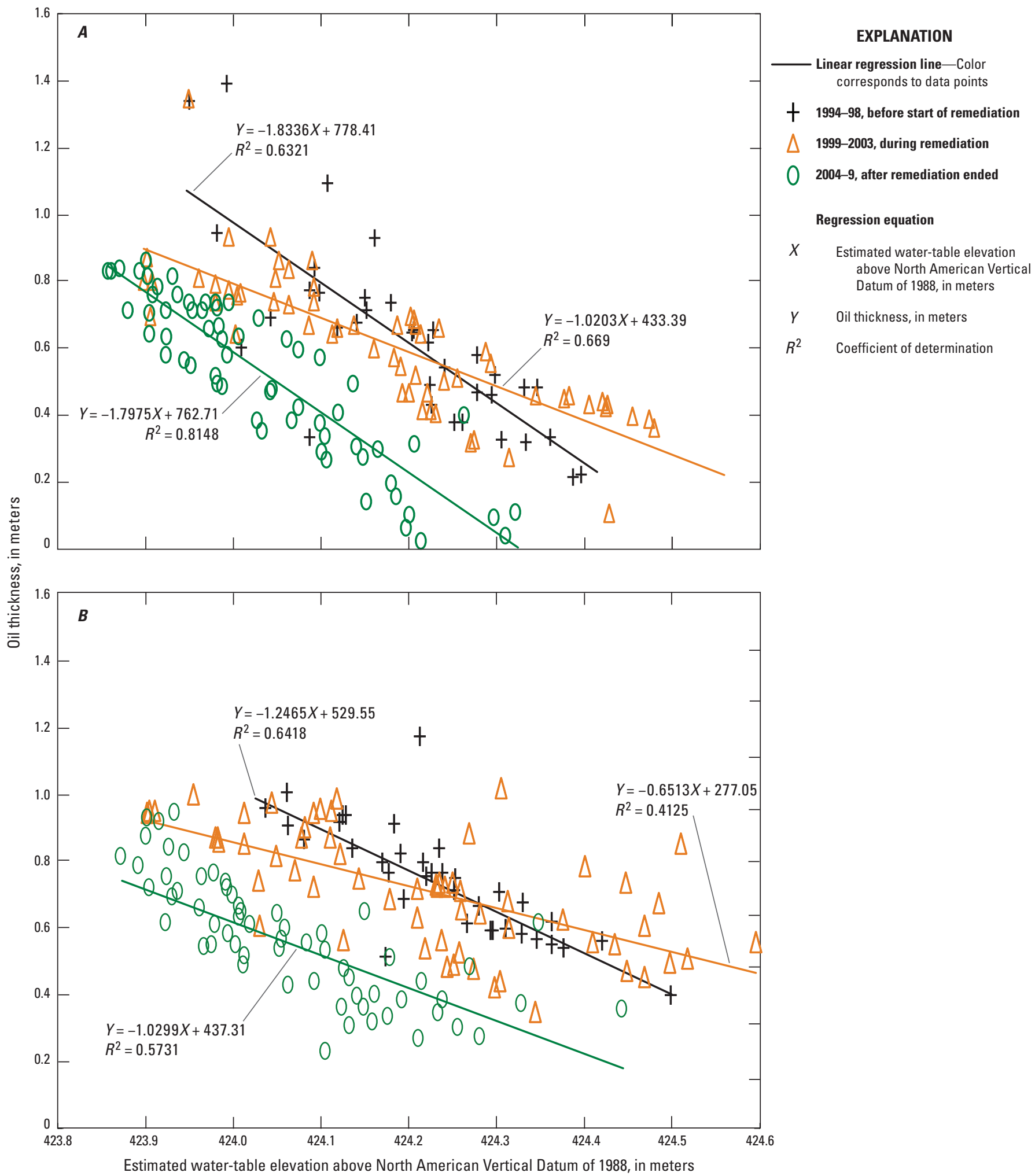

Figure 8. Relation between estimated water-table elevation and oil thickness in wells at the Bemidji, Minnesota, north oil pool. $A$, well $301 \mathrm{~A} ; B$, well $315 ; C$, well 980 . The slope of the regression line through the data collected during the remediation is shallower than the regression lines before and after the remediation. 


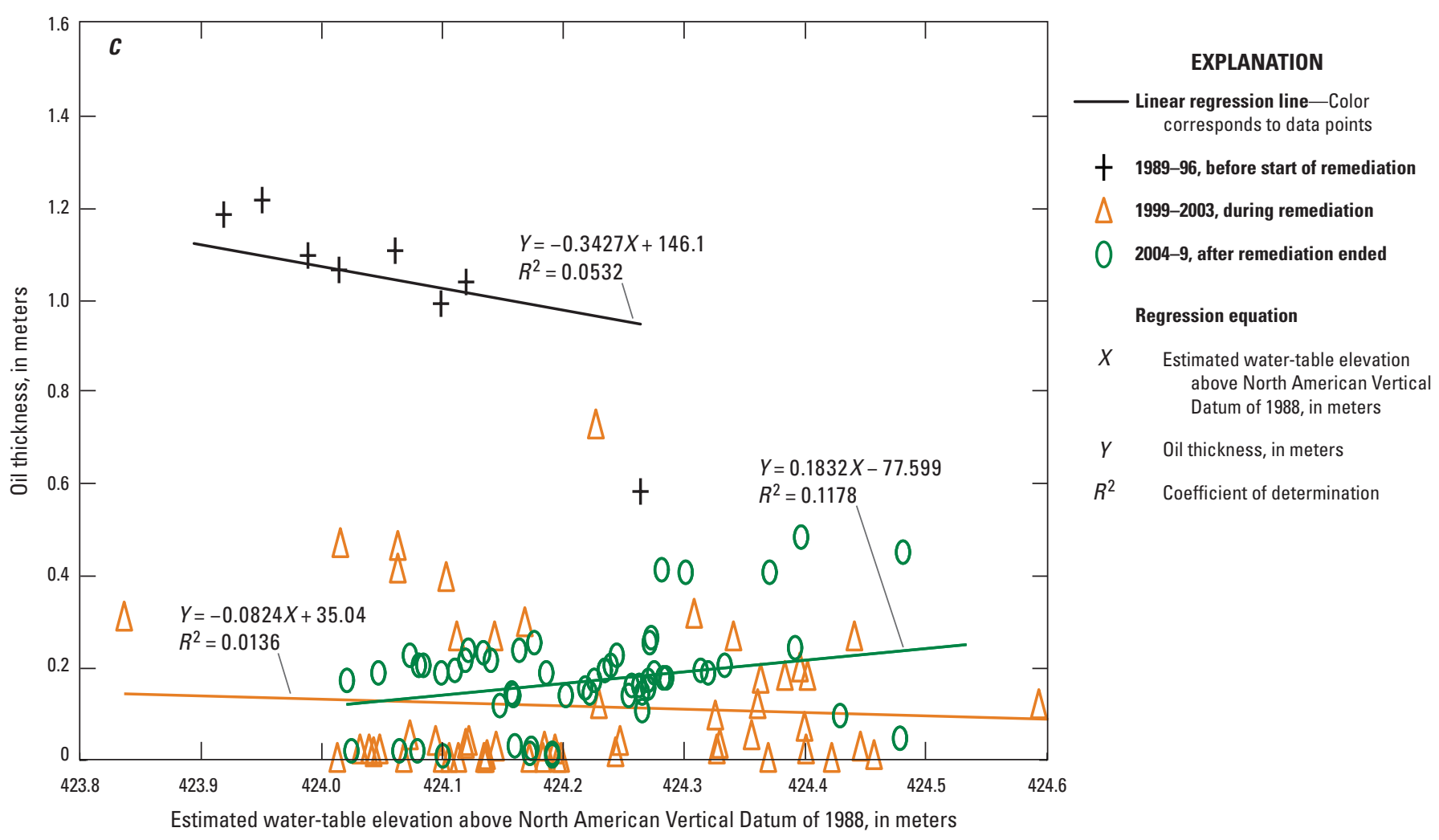

Figure 8. Relation between estimated water-table elevation and oil thickness in wells at the Bemidji, Minnesota, north oil pool. $A$, well 301A; $B$, well $315 ; C$, well 980 . The slope of the regression line through the data collected during the remediation is shallower than the regression lines before and after the remediation.-Continued

effect of the remediation effort at well 980. The approximate vertical distance between the before-regression line (black) and the after-regression line (green) is about $0.7-0.9 \mathrm{~m}$. This indicates that at a given water level, the oil thicknesses were about $0.7-0.9 \mathrm{~m}$ less after the remediation compared to before the remediation. The comparatively large effect of the remediation in reducing oil thicknesses at well 980 largely is due to the proximity of the well to the drain $(3.0 \mathrm{~m})$ at the south oil pool (fig. 1). Although oil thicknesses were reduced substantially at well 980 , the after-remediation data indicate that $0.1-0.4 \mathrm{~m}$ of oil nevertheless remained in the subsurface and the remediation did not achieve the sheen objective. Note that the slope of the regression line for the measurements made after the remediation ended is positive (fig. $8 C$ ) instead of negative, as is the case for wells $301 \mathrm{~A}$ and 315 (figs. $8 \mathrm{~A}$ and $B$ ). This positive slope results because the well is only $3.0 \mathrm{~m}$ from remediation well RW-1S and oil thicknesses at well 980 began increasing immediately after the remediation ended. In other words, wells that were farther away from a remediation well had a shallower gradient and reflected a smaller effect of the remediation.

The previously mentioned results are consistent with the study hypothesis, that the remediation would not achieve the objective of removing oil to a sheen in all wells. It is unclear if the oil-recovery system was able to remove oil from the groundwater system to a sheen in any area, even within 2-5 m of the remediation wells, as required by the State regulatory agency. In general, changes in average oil thickness at the north and south oil pools were relatively minor from before to after the remediation. These results illustrate that using oil-thickness data to evaluate the effects of remediation of a crude-oil contamination site does not produce a useful or meaningful measure.

The results from this study are consistent with data from previous studies. A negative correlation typically exists between water-table elevation and LNAPL thickness in monitoring wells at most spill sites (Kemblowski and Chiang, 1990; Charbeneau and others, 1999). The most likely mechanisms for this relation are as follows: (1) increased oil entrapment and decreased mobile oil in high water-table conditions causes a reduction in oil thickness compared to low water-table conditions, and (2) under nonequilibrium conditions, monitoring wells act as conduits for preferential flow of liquids (Kemblowski and Chiang, 1990; Marinelli and Durnford, 1996). This second point, however, is only a factor in low permeability formations and thus does not apply to the Bemidji site, which has a relatively high permeability as described previously. Hysteresis in soil fluid retention curves also affects the oil thickness in wells. At the same water-table elevation, oil thicknesses tend to be greater during a period of water-table decline than during a period of water-table rise (Marinelli and Durnford, 1996). 
A negative correlation between the estimated watertable elevation and measured oil thickness is evident in most of the data collected from wells 301A, 315, and 980 (fig. 8). The slopes of all the data are negative except for data collected after the remediation at well 980 (fig. 8C). As described earlier, this positive slope results at well 980 because this well is only $3.0 \mathrm{~m}$ from remediation well RW-1S and oil thicknesses began increasing immediately after the remediation ended. The remediation depleted oil to an increasingly greater extent with closer proximity to each of the remediation wells. After the remediation ended, oil continued to flow toward each remediation well because the oil surface still sloped in that direction and because of a nonequilibrium hydraulic condition. This redistribution of the oil after the remediation ended is only evident in the data from well 980 , however, as reflected in the positive slope of the postremediation data in figure $8 C$, because of it being closer to a remediation well compared to wells $301 \mathrm{~A}$ and 315 .

As illustrated in the results from wells 301A, 315, and 980 (fig. 8), the relation between the measured oil thickness and estimated water-table elevation is inconsistent. This inconsistency was observed in the data across the site. The negative correlation between these two datasets was not prevalent at all wells (including wells not shown in this report); however, for virtually all wells where more than about 40 oil-thickness measurements were made before, during, and after the remediation, a negative correlation was observed. Also, most of the wells where oil-thickness measurements were made were more than $10 \mathrm{~m}$ from a remediation well and consequently indicated lesser effects from the remediation. Because of the hysteretic relation between oil thickness and water-level fluctuations, having enough measurements is critical to demonstrate the negative relation between oil thickness and estimated water level. Additional research is needed to better clarify the importance and relevance of correlating these data as a tool in evaluating crude-oil contamination and some initial ideas are discussed here.

Study results indicate that the previously mentioned analysis of plotting oil thickness versus estimated water level could prove beneficial at existing crude-oil spill sites such as refineries or storage facilities. For example, one procedure that could be used would be to monitor oil thickness and plot these data versus water-table elevation weekly to monthly for 1-year periods. Changes in slope or changes in offset in these plots may indicate a change to the amount of product in the system.

The most apparent change that could indicate product being added to a groundwater system is an increase in the vertical offset in the thickness to water-level relation. In all three examples (fig. 8), the after-remediation oil thicknesses were noticeably lower than the before-remediation oil thicknesses at the same water level. If enough data are collected over the course of several years, the data could be grouped (for example, by years) to look at year-to-year shifts in the offset. If oil had been added to the system, a vertical increase in the offset is expected to be apparent in the data. This would be the reverse of what was observed in this study, when the offset decreased after oil was removed (fig. 8). Evaluating the data this way is much more effective for detecting and evaluating changes to oil in the system compared to simply evaluating average oil thickness over time.

The slopes of the regression lines in figure 8 also change consistently and indicate a sensitivity of the oil-thickness/ water-level relation to changes in gradients and stresses present in the system. The slope decreased during the remediation for all three wells. In addition, the after-remediation slope is rotated counterclockwise compared to the before-remediation slope for all three wells. For well 980 (fig. 8C), the slope is rotated so far counterclockwise that it became positive. This change in slope could be due to the redistribution of the oil after the remediation. Redistribution of oil also occurred at wells $301 \mathrm{~A}$ and 315 , but to a lesser degree, because they are farther from a remediation well. The rate at which oil is being added in the vicinity of a monitoring well seems to be related to how much the slope of the regression line is rotated compared to the previous condition.

\section{Remediation Plume in Groundwater}

The following subsections of the report describe the remediation plume at the Bemidji site during the remediation completed in 1999-2003. Included in these sections are descriptions of field water-quality properties of dissolved oxygen, specific conductance, temperature, and $\mathrm{pH}$ in groundwater in relation to the remediation plume; estimates of the remediation plume location; and measurements of benzene, toluene, ethylbenzene, and xylene (BTEX) in relation to the remediation plume.

\section{Field Water-Quality Measurements and the Remediation Plume}

Crude oil trapped in the unsaturated zone and near the water table has provided a continuous source of hydrocarbon contamination to groundwater at the site since 1979 (Essaid and others, 2011). Hydrocarbons have dissolved from the oil at varying rates, changing the source composition and forming a groundwater plume. The dissolved compounds have been transported in the saturated zone, forming a plume of hydrocarbons, associated degradation intermediates, and end products (herein termed the "natural attenuation plume"). By August 1998, just before the start of the remediation, the natural attenuation plume extended from about $50 \mathrm{~m}$ downgradient from the infiltration gallery to about $250 \mathrm{~m}$ farther downgradient (fig. $9 A$; table 3). The natural attenuation plume is herein delineated by dissolved oxygen concentrations measured in observation wells of less than $1.0 \mathrm{mg} / \mathrm{L}$ and total BTEX concentrations exceeding about 10 micrograms per liter.

Research completed at this site by Bennett and others (1993) indicates that the combination of dissolved oxygen and specific conductance was a good indicator of biodegradation processes (also National Research Council, 2000). In this 


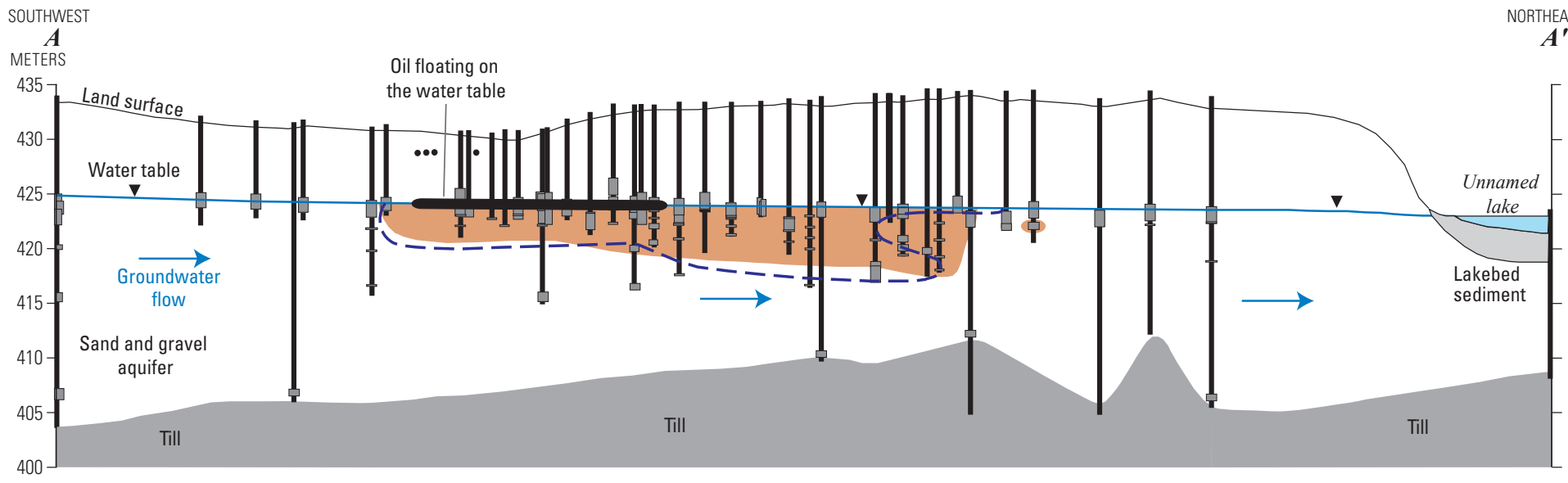

400

B. July 2003 remediation plume location based on dissolved oxygen measurements and the computed average transport velocity of 0.3 meter per day

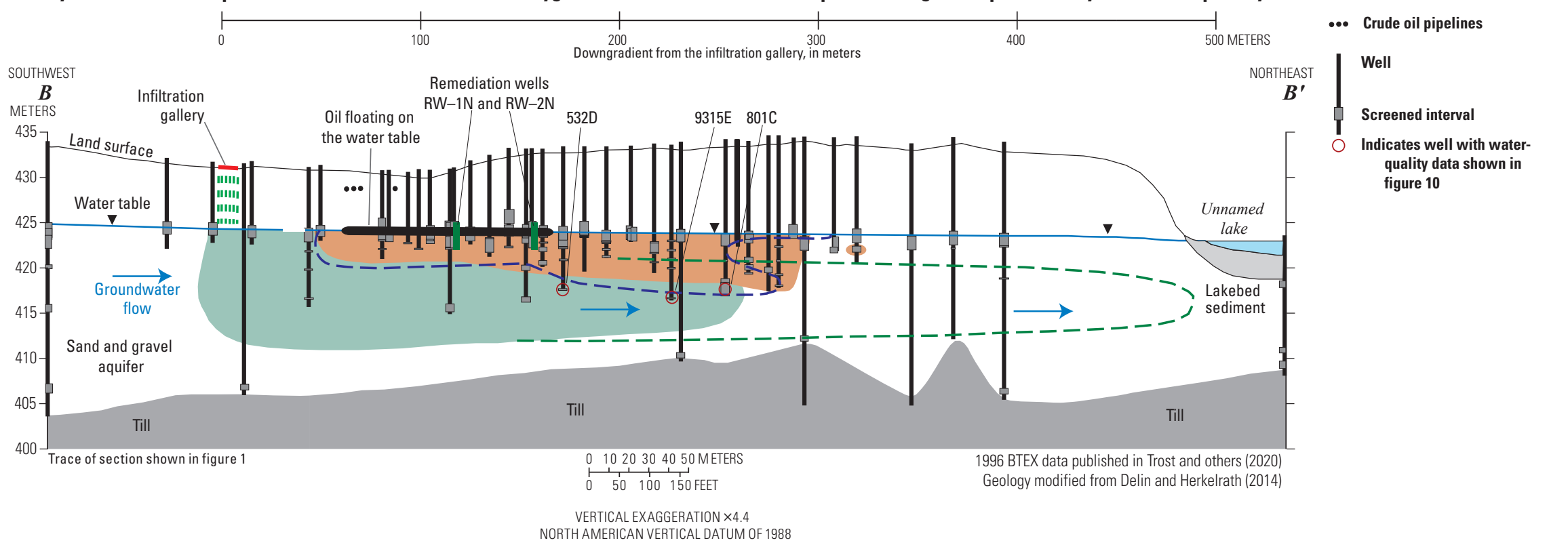

Figure 9. Plumes in the saturated zone at the Bemidji site. $A$, natural attenuation plume in July 1998, before the start of the remediation; $B$, remediation and natural attenuation plumes in July 2003 based on dissolved oxygen measurements and the computed average remediation plume transport velocity of 0.3 meter per day. [Trost and others, 2020; Delin and Herkelrath, 2014]
EXPLANATION

atural attenuation plume; dissolved oxygen less the
1.0 milligram per liter

Observed remediation plume

- Benzene, toluene, ethylbenzene, and xylene (BTEX) greater than 10 micrograms per lite in 1996

- Estimated remediation plume location based on average transport

Crude oil pipelines 
Table 3. Approximate distance downgradient from the infiltration gallery for the natural attenuation plume compared to estimates for the remediation plume based on observed dissolved oxygen measurements, the maximum observed velocity of 0.9 meter per day based on first arrival of anoxic water 160 meters downgradient from the infiltration gallery, and the average velocity of 0.3 meter per day based on all dissolved oxygen first-arrival data.

[NAP, natural attenuation plume; DO, dissolved oxygen; m/d, meter per day; --, not applicable; ?, location of the NAP and remediation plume were uncertain because of an insufficient number of observation wells downgradient from about 240 meters from the infiltration gallery]

\begin{tabular}{|c|c|c|c|c|c|}
\hline \multirow[b]{3}{*}{ Sampling date } & \multirow[b]{3}{*}{ Time (years) ${ }^{1}$} & \multicolumn{4}{|c|}{ Approximate distance downgradient from the infiltration gallery (meters) } \\
\hline & & \multirow[b]{2}{*}{ For the NAP } & \multicolumn{3}{|c|}{ For the remediation plume } \\
\hline & & & $\begin{array}{c}\text { Based on } \\
\text { observed DO } \\
\text { measurements }\end{array}$ & $\begin{array}{l}\text { Based on maximum } \\
\text { velocity of } 0.9 \mathrm{~m} / \mathrm{d}\end{array}$ & $\begin{array}{l}\text { Based on average velocity of } \\
\qquad 0.3 \mathrm{~m} / \mathrm{d}\end{array}$ \\
\hline August 1998 & -- & 300 & -- & -- & -- \\
\hline July 1999 & 0.5 & 300 & 160 & 150 & 50 \\
\hline August 2000 & 1.6 & 300 & 240 & 510 & 170 \\
\hline July 2001 & 2.5 & $300 ?$ & $?$ & 840 & 280 \\
\hline July 2002 & 3.5 & $340 ?$ & $?$ & 1,170 & 390 \\
\hline July 2003 & 4.5 & $340 ?$ & $?$ & 1,470 & 490 \\
\hline August 20042 & 5.6 & $340 ?$ & ? & 1,830 & 610 \\
\hline
\end{tabular}

1Time, in years, since the beginning of the remediation in January 1999.

${ }^{2}$ This time was 0.6 year after the end of the remediation in December 2003.

study, it was assumed that a dissolved oxygen concentration of less than $1.0 \mathrm{mg} / \mathrm{L}$ in groundwater was representative of anoxic conditions in the saturated zone because of microbial biodegradation associated with the crude-oil contamination. By comparison, background dissolved oxygen concentrations typically are in the range of 6-7 mg/L in uncontaminated areas at the site. Similarly, background specific conductance concentrations in groundwater at the site typically range from 300 to $500 \mu \mathrm{S} / \mathrm{cm}$, which increase to between 500 and $900 \mu \mathrm{S} / \mathrm{cm}$ in areas affected by the crude-oil contamination.

Most of the water injected through the infiltration gallery was intended to be withdrawn by remediation wells RW-1N and RW-2N at the north oil pool (Natural Resources Engineering Company, 1998); however, some of this injected water migrated as a remediation plume of groundwater upgradient from and beneath the existing natural attenuation plume (fig. 9B). The total amount of groundwater injected into the infiltration gallery during the remediation is unknown. In July 1999, 6 months after the remediation started, anoxic water was detected for the first time upgradient from and beneath the natural attenuation plume in numerous observation wells. This anoxic water is herein termed the "remediation plume" and was detected as far downgradient as $160 \mathrm{~m}$ in July 1999 (table 3); thus, the remediation and natural attenuation plumes seemed to have merged. Without additional data such as isotopes or BTEX concentrations, it was not possible to distinguish between the anoxic waters of the natural attenuation and remediation plumes. The approximate locations of the remediation plume listed in table 3 (and shown in fig. 9B) were estimated based on the first detection of anoxic water in the indicated observation wells. Unfortunately, we did not have additional wells in the downgradient areas of the remediation plume to collect groundwater samples and thus more accurately delineate its extent through time. The times listed in table 3 are considered conservative because the anoxic water could have reached a given well before the indicated sampling date.

Based on detection of anoxic water in July 1999 at a location $160 \mathrm{~m}$ downgradient from the infiltration gallery, a maximum velocity of $0.9 \mathrm{~m} / \mathrm{d}$ was computed for the leading edge of the remediation plume for the first 6 months of the remediation. It should be recognized that this rate likely is less than the true maximum rate because our once-per-year sampling frequency was inadequate to detect when the remediation plume first passed any of the wells. The computed rate of $0.9 \mathrm{~m} / \mathrm{d}$ is slightly greater than the estimated natural lateral pore-water velocity of about $0.7 \mathrm{~m} / \mathrm{d}$ based on results from previous aquifer hydraulic property analyses completed at the north oil pool (Essaid and others, 2003, 2011). It is hypothesized that this slightly greater rate of lateral plume migration is due to the increased recharge through the infiltration gallery of $73 \mathrm{~L} / \mathrm{min}$ ( 38,400 cubic meters per year) over the $37-\mathrm{m}^{2}$ surface area of the infiltration gallery for 5 years. This application rate is equivalent to about $1,040 \mathrm{~m} / \mathrm{yr}$ of recharge applied to the $37-\mathrm{m}^{2}$ infiltration gallery, or about $3,000-10,000$ times the natural recharge rate of $0.1-0.3 \mathrm{~m} / \mathrm{yr}$ (Delin and Herkelrath, 2005). The amount pumped from the two north oil pool remediation wells was inadequate to remove all the water injected from remediation wells at the north, middle, and south oil pools. Much of the infiltrating water bypassed the remediation wells and created the remediation plume, as shown in figure $9 B$. 
In August 2000, 1.5 years after the remediation started, the remediation plume was detected about $240 \mathrm{~m}$ downgradient from the infiltration gallery. This translates to a minimum velocity of $0.4 \mathrm{~m} / \mathrm{d}$ for the leading edge of the remediation plume based on this single data point. This was the last sampling point where the remediation plume was detected because of an insufficient number of observation wells farther downgradient. After termination of the renewed remediation in December 2003, anoxic conditions persisted beneath the infiltration gallery for about 1.5 years through July 2005 before oxygen concentrations increased in July 2006. The anoxic remediation plume persisted beneath parts of the natural attenuation plume at least through July 2009, 5.5 years after the remediation ended.

Time-series graphs of selected field water-quality data measured in three wells support the hypothesis of the migration of the remediation plume downgradient. Wells 532D, $9315 \mathrm{E}$, and $801 \mathrm{C}$ are screened about $15 \mathrm{~m}$ below land surface, near the middle of the saturated zone, and within the remediation plume (fig. 9B). The locations of these wells are within the predicted downgradient end of the remediation plume (table 3).

Dissolved oxygen decreased in all three wells from between 3 and 4 to less than $1 \mathrm{mg} / \mathrm{L}$ during the first 2 years of the remediation, clearly indicating the progressive arrival of the remediation plume at these locations (fig. 10). Between 1999 and 2008, dissolved oxygen concentrations generally remained anoxic, being less than $1 \mathrm{mg} / \mathrm{L}$, at all three locations. In other words, the remediation plume persisted for about 5 years after the remeditation ended as far as $236 \mathrm{~m}$ downgradient from the infiltration gallery. The spike in dissolved oxygen for well $801 \mathrm{C}$ in 1999 and for 532D in 2007 are due to oxygen being introduced during sampling and are not related to the remediation. Beginning in 2009, 6 years after termination of the remediation, dissolved oxygen concentrations noticeably increased at wells 532D and 9315E, 160 and $214 \mathrm{~m}$, respectively, downgradient from the infiltration gallery. These changes indicate that biodegradation of hydrocarbons in the remediation plume was slowing and less oxygen was being consumed, and the system was transitioning back to its preremediation state.

Beginning in 2000-1, specific conductance concentrations noticeably increased in all three wells from about 400 to more than $700 \mu \mathrm{S} / \mathrm{cm}$ (fig. 10). After reaching a peak concentration in 2002-3, specific conductance concentrations decreased in all three wells. The specific conductance reached preremediation concentrations in wells $532 \mathrm{C}$ and $9315 \mathrm{E}$ by $2008-10$. Similar to the changes in dissolved oxygen concentrations during this period, these changes in specific conductance are the result of the remediation plume migrating downgradient through 2008 followed by dissipation of the remediation plume beginning in 2009 and the system transitioning back to its preremediation state.

In general, $\mathrm{pH}$ fluctuated near 7.0 in the three wells before, during, and after the remediation (fig. 10). There was a slight decrease in groundwater $\mathrm{pH}$ in all three wells from around 7.2-7.4 units before the start of the remediation in 1998 to $6.8-7.0$ units by 2010 (fig. 10). The slight decrease and small fluctuations in $\mathrm{pH}$ are unlikely to be related to the remediation, however, but instead are likely related to instrument and sampling variability.

Groundwater temperatures measured in all three wells increased steadily during and after the remediation from about $8-9{ }^{\circ} \mathrm{C}$ to $9-10^{\circ} \mathrm{C}$ by 2008 (fig. 10). These increasing groundwater temperatures likely reflect migration of the remediation plume downgradient, as further demonstrated by Warren and Bekins (2018).

Warren and Bekins (2018) created a model of subsurface heat generation and transport that helped clarify the contribution of heating from microbial activity and infrastructure, such as the underground pipelines, to observed temperature increases at this site. They created a steady-state, twodimensional, heat transport model using previously published property values for physical, chemical, and biodegradation properties. Simulated temperature distributions matched the observed average annual temperatures measured in the contaminated area at the site within less than $0.2^{\circ} \mathrm{C}$ in the unsaturated zone and $0.4{ }^{\circ} \mathrm{C}$ in the saturated zone. The model results confirmed that the observed increased subsurface heat was due primarily to heat from the pipelines and methane oxidation in the unsaturated zone and resulted in an increase of $3.6^{\circ} \mathrm{C}$ in average annual temperature.

The insufficient frequency of sample collection, an insufficient number of wells downgradient, and an insufficient number of wells within the remediation plume at deeper depths in the aquifer (fig. 9) prevented us from drawing more wide-ranging conclusions from the field water-quality data. Nevertheless, it is clear these simple, inexpensive, and readily available field water-quality data are useful in evaluating the effects of remediation at a crude-oil spill site.

\section{Estimates of the Remediation Plume Location}

Based on the maximum observed velocity of $0.9 \mathrm{~m} / \mathrm{d}$, the approximate distance downgradient from the infiltration gallery for the leading edge of the remediation plume was estimated from August 2000 through August 2004 (table 3). Expansion of the remediation plume beyond our most downgradient 240-m observation well sampled in August 2000 likely was affected by several factors. Although the microbial populations were not fully developed at the beginning of the remediation (Bekins and others, 1999), biodegradation is a natural attenuation process that undoubtedly attenuated the remediation plume as it migrated downgradient. The remediation plume also likely expanded in an elliptical pattern because of diffusion and dispersion, and movement of the leading edge slowed down in time. It is likely that expansion of the remediation plume also was affected by variable injection rates in the infiltration gallery and variable pumping rates from the remediation wells. 

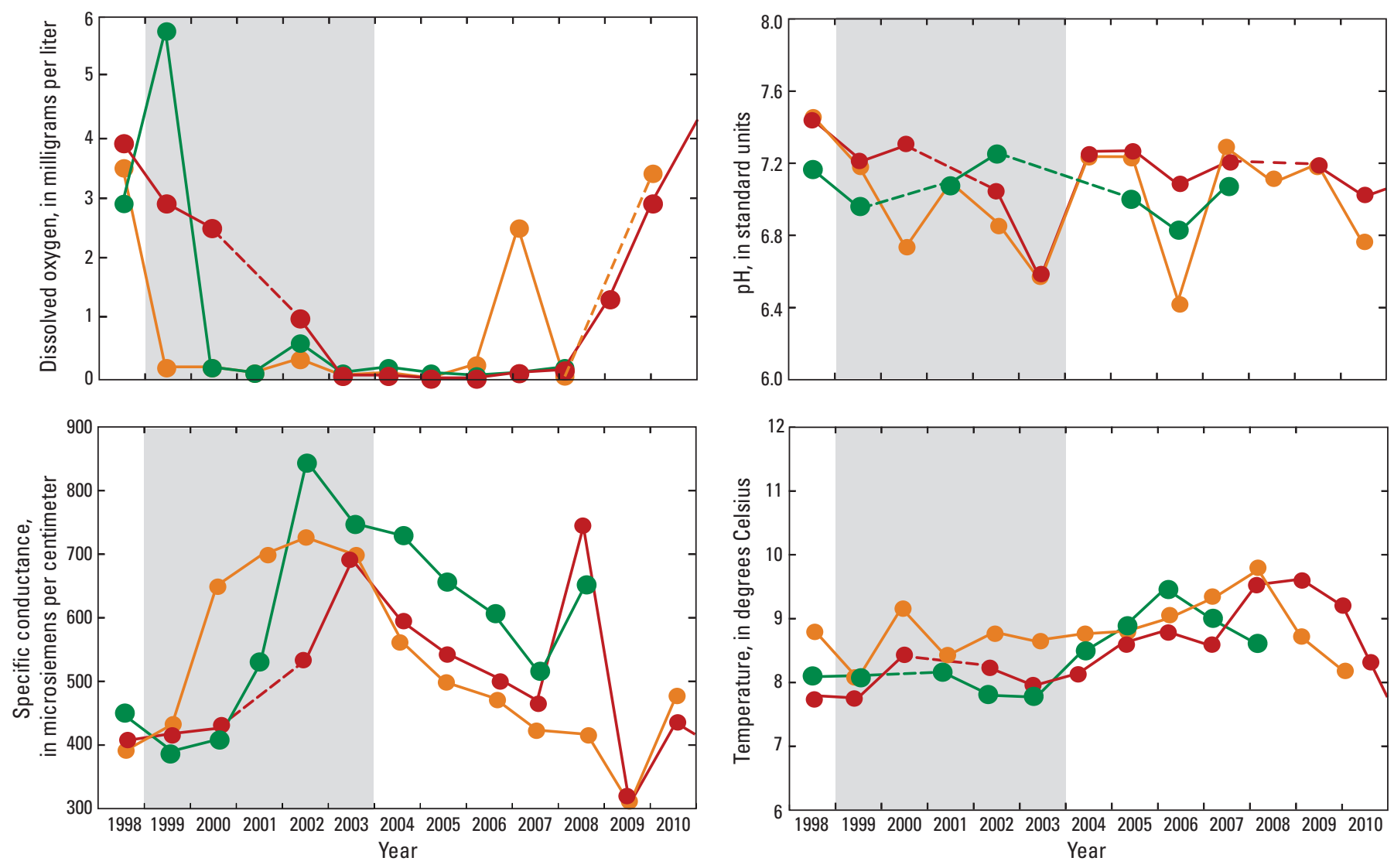

EXPLANATION

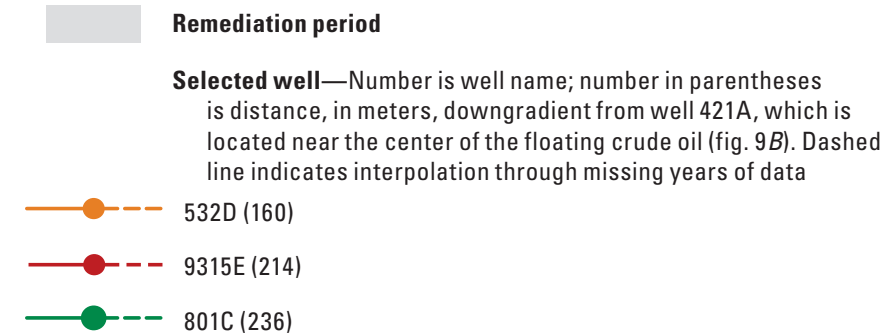

Figure 10. Concentrations of dissolved oxygen, pH, specific conductance, and temperature for selected wells from 1998 through 2010. The locations of these three wells are shown in figure $9 B$.

To account for effects of the previously mentioned processes, the average remediation plume velocity was computed based on data from all the observation wells. This average rate of $0.3 \mathrm{~m} / \mathrm{d}$ was used as a conservative estimate for the location of the leading edge of the remediation plume for all sampling periods after August 2000 (table 3). Assumptions associated with using this estimate are as follows: (1) the injection rate into the infiltration gallery was constant during the remediation, (2) groundwater recharge and discharge rates remained constant, and (3) biodegradation, diffusion, and dispersion did not substantially attenuate or accelerate movement of the remediation plume beyond this average rate. The actual injection rates into the infiltration gallery were unknown. Based on the average velocity of $0.3 \mathrm{~m} / \mathrm{d}$ and the previously mentioned assumptions, the remediation plume would have reached a location about $500 \mathrm{~m}$ downgradient from the infiltration gallery by July 2003, 5 months before the end of the remediation (table 3; figure $9 B$ ).

\section{Benzene, Toluene, Ethylbenzene, and Xylene and the Remediation Plume}

In 2007, 3.5 years after the remediation ended, the remediation plume was still evident in the flow system at least $240 \mathrm{~m}$ downgradient from the infiltration gallery (fig. 10). Crude oil was also observed within the subsurface near the infiltration gallery in 2017 during installation of an observation well. However, BTEX was not detected in association with the remediation plume in 2007 within about $140 \mathrm{~m}$ 
downgradient from the LNAPL source (Amos and others, 2012), which may be an indication of anaerobic BTEX degradation.

Microbial populations associated with the remediation plume likely were not fully developed when the remediation began in 1999, based on data collected at the site by Bekins and others (1999). This would particularly be the case within the less contaminated parts of the unsaturated and saturated zones of the aquifer system beneath the infiltration gallery. It likely took a year or more for the aerobic and anaerobic microbial populations to become established to the point where degradation was noticeable. Modeling by Essaid and others (1995) indicated that the microbial populations in the natural attenuation plume reached their observed values in about 4 years. Degradation likely was rapid in the remediation plume as the microbial populations became established. Results of in situ microcosm experiments (Cozzarelli and others, 2010) indicate that BTEX was almost totally degraded within about 400 days of introduction into the natural attenuation plume where the microbial populations were fully established. Based on these results, it is expected that the BTEX introduced by the disposal of pumped water from the remediation wells into the upgradient infiltration gallery during the remediation would have been fully degraded by natural attenuation by 2007 , and probably much sooner. Although groundwater associated with the remediation plume was depleted of BTEX, the water remained anoxic at least through July 2009, 5.5 years after the remediation ended. Instead, the depleted dissolved oxygen that persisted after the remediation ended likely was associated with a plume of nonvolatile dissolved organic carbon at the site, which increased from 1992 until at least 2010 (Amos and others, 2012; Ng and others, 2014; Bekins and others, 2016).

\section{Unsaturated-Zone Vapor}

The general hypothesis for vapor transport in this study was that crude-oil removal during the remediation would not have a substantial effect on vapor indicators of biodegradation (methane, carbon dioxide, and oxygen) in the unsaturated zone. This hypothesis resulted in part from the oil-saturation work of Herkelrath (1999), which implied that 75-84 percent of the oil in the subsurface before the start of the remediation would remain after the remediation ended (table 1). Because the estimated remaining source oil was substantial, it was reasonable to hypothesize that vapor transport above the source oil also would not change substantially. Methane and carbon dioxide are produced and oxygen consumed by biodegradation in the capillary zone above the floating crude oil (Chaplin and others, 2002). Consequently, total hydrocarbon biodegradation rates and hydrocarbon concentrations in the unsaturated zone are directly proportional to methane and carbon dioxide gas fluxes and inversely proportional to oxygen gas flux (Chaplin and others, 2002).

The vapor sampling wells (figs. 1, 4, and 11) are spaced somewhat evenly across the north oil pool from well 604G near the upgradient end of the oil. Well $301 \mathrm{G}$ is above the center of the oil body, well $601 \mathrm{G}$ is farther downgradient and beyond the north oil pool depression, and well $533 \mathrm{G}$ is at the downgradient end of the oil pool (figs. 1 and 4). Thus, data from these wells give a good representation of spatial and temporal changes in vapor concentrations across the north oil pool. The data shown in figure 11 generally indicate either no change during the remediation or a continuation of the trend that began before the remediation.

Generally, the trends in vapor concentrations were indicative of long-term (20+ year) oil biodegradation processes rather than remediation activities and support our hypothesis that crude-oil removal would not have a substantial effect on vapor concentrations in the unsaturated zone. There was a general decrease in methane concentrations during and after the remediation in the unsaturated zone above the upgradient, more weathered crude oil near wells $604 \mathrm{G}$, port 3 , and $301 \mathrm{G}$, port 4 (fig. 11). At well $301 \mathrm{G}$, port 4, this decrease began in 1997, before the start of the remediation. This decrease is thought to be unrelated to the remediation but instead the result of reduced rates of biodegradation and methane production from the increasingly more weathered crude oil (Amos and others, 2005). The crude oil is much more weathered in this area beneath the north oil pool land-surface depression because of increased recharge that has increased downward transport of microbial growth nutrients to the oil body, thus enhancing oil degradation (Bekins and others, 2005). The increase in methane concentrations at well $601 \mathrm{G}$, port 2 , and to a lesser extent at well $533 \mathrm{G}$, port 2, toward the end of the remediation are thought to largely be caused by a natural shift in microbial population from iron-reducing to methanogenic conditions in the downgradient, less weathered parts of the oil (Amos and others, 2012). In general, methane concentrations in the unsaturated zone above the downgradient, less weathered parts of the crude oil near well $533 \mathrm{G}$ remained fairly constant during and after the remediation (fig. 11).

Similarly, carbon dioxide, nitrogen, and oxygen concentrations were largely unaffected by the remediation. The slight increase in the nitrogen concentrations at most of the wells plus the decrease in carbon dioxide concentrations at well $601 \mathrm{G}$, port 2, during the remediation likely were due to advective gas flux rather than as a result of the remediation itself (Amos and others, 2005). The decrease in oxygen and carbon dioxide, similar to the slight increase in methane production at well $533 \mathrm{G}$, port 2 , is caused by a shift to methanogenic conditions. There was a natural shift in microbial 


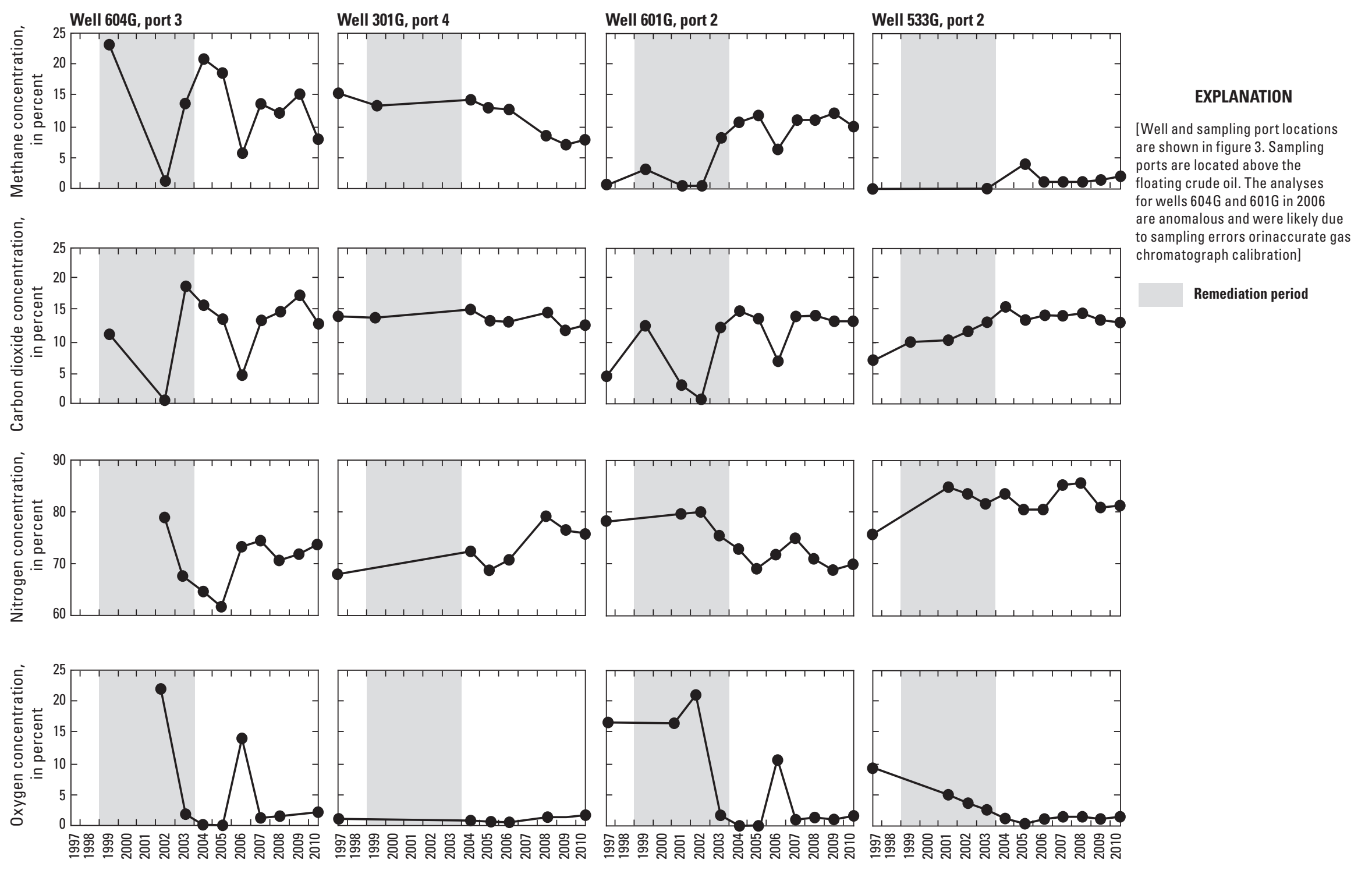

Figure 11. Time series of methane, carbon dioxide, nitrogen, and oxygen vapor concentrations during 1997-2010 for selected vapor sampling ports at the Bemidji, Minnesota, north oil pool, in percentage by volume. 
population from iron-reducing to methanogenic conditions in the downgradient, less weathered parts of the oil, as well as a depletion in oxygen associated with degassing caused by methane production (Amos and others, 2005). The analyses of methane, carbon dioxide, and oxygen for wells $604 \mathrm{G}$ and $601 \mathrm{G}$ in 2006 are anomalous and were likely due to sampling errors or inaccurate GC calibration.

\section{Summary}

On August 20, 1979, about 16 kilometers northwest of Bemidji, Minnesota, an 86-centimeter-diameter crude-oil pipeline burst, spilling about 1.7 million liters of crude oil onto glacial outwash deposits. A 1997 investigation by the pipeline company indicated that 575,500 liters of oil remained in the subsurface after their initial remediation efforts. A previous study by Herkelrath in 1999 estimated that 241,000 liters of oil remained at the north and south oil pools and that 7 to 25 percent of the oil in the subsurface could be recovered, based on the concept of residual oil saturation.

Remediation at the Bemidji site was renewed in 1999 at the direction of the Minnesota Pollution Control Agency. Five remediation wells were installed by the pipeline company with the stated objective to remove the crude oil to a sheen in the observation wells. The renewed remediation from 1999 to 2003 resulted in removal of about 115,000 liters of crude oil from the site, which represented 36-41 percent of the 281,000-317,000 liters of oil that was estimated by the U.S. Geological Survey to be present in 1998 before the start of the remediation. The 115,000 liters of oil removed represents only 19 percent of the Natural Resources Engineering Company estimate of 575,500 liters of oil in the subsurface before the start of the remediation.

The objective of reducing oil thickness in wells to a sheen was not achieved. Average oil thickness in 18 wells at the north oil pool increased slightly during the remediation, from about 0.7 meter in 1998, 6 months before the start of the remediation, to about 0.8 meter in 2003, during the last year of the remediation. Average oil thicknesses at the south oil pool remained unchanged at about 0.3 meter. This lack of change or slight increase in average oil thickness, as well as seasonal fluctuations in average oil thickness, do not seem to be linked to the remediation but are more likely the result of natural fluctuations of recharge and discharge from the aquifer. The rebound in crude-oil thicknesses after termination of the remediation observed in the observation wells most likely resulted from lateral migration of the light nonaqueous phase liquid within the capillary zone rather than infiltration from the unsaturated zone.

A negative correlation exists between water-table elevation and crude-oil thickness at many locations at the Bemidji site. The slope of the regression line through these data during the remediation is shallower than for the regression line before or after the remediation. The cause of this reduced slope during the remediation was not examined in detail in this study. The negative correlation between these two datasets was not evident at all wells. Additional research is needed to better clarify the importance and relevance of correlating these data as a tool in evaluating crude-oil contamination and some initial ideas are discussed here.

For all the wells in this report where crude-oil thickness was plotted against water-table elevation, there is a clear vertical offset between the linear regression lines for before the remediation started and after it ended. We concluded that under nonremediation conditions, a vertical shift in the relation between oil thickness and estimated water level indicates a change in the amount of free product in the system, or a change in the properties of the free product. This shift was not apparent when simply calculating the average oil thicknesses across the site.

Another use for these data correlating water-table elevation and crude-oil thickness could be to evaluate how the regression lines rotate in time from before, to during, and after remediation or because of the addition of oil in the case of a pipeline leak. The shallower slope from before compared to during the remediation resulted from the removal of oil. If oil were added to the system, because of a pipeline leak for example, the regression line would similarly have a shallower slope, or be rotated counterclockwise, compared to before the addition of oil.

The remediation expanded the dissolved anoxic plume of groundwater upgradient from and beneath the existing natural attenuation plume. Beginning in 2000-1, for example, specific conductance concentrations noticeably increased in many wells at the north oil pool from about 400 to more than 700 microsiemens per centimeter. The rapid expansion of the anoxic and elevated specific conductance plume indicates that the remediation contributed substantial amounts of biodegradable dissolved organic carbon to groundwater through the infiltration gallery. Anoxic water was detected upgradient from and beneath the natural attenuation plume in numerous observation wells 6 months after the remediation started in January 1999. Based on the detection of anoxic water in July 1999, 160 meters downgradient from the infiltration gallery, a maximum transport rate of 0.9 meter per day was estimated for the leading edge of the remediation plume. This rate is slightly greater than the estimated natural lateral porewater velocity of about 0.7 meter per day based on results from previous hydraulic property analyses at the site (Essaid and others, 2003, 2011). It is hypothesized that this higher rate of lateral plume migration is due to the greatly increased recharge through the infiltration gallery of 73 liters per minute over 37 square meters for 5 years.

The remediation affected most of the field water-quality properties, most notably dissolved oxygen and specific conductance. As mentioned previously, beginning in 2000-1, specific conductance concentrations noticeably increased in many wells at the north oil pool from about 400 to more than 700 microsiemens per centimeter. The trends in vapor data collected before, during, and after the remediation also 
generally support our hypothesis that crude-oil removal by the pipeline company would not have a substantial effect on vapor concentrations in the unsaturated zone. Although there were some small changes in the concentrations of methane, carbon dioxide, nitrogen, and oxygen, they were not coincident with the beginning or cessation of the remediation and are therefore thought to be the result of other factors affecting biodegradation rates. A decrease in methane concentrations in one representative well, for example, is thought to be the result of reduced rates of biodegradation and methane production from the increasingly more weathered crude oil.

Study results demonstrated that oil-phase recovery at this site is challenging; considerable volumes of mobile and entrapped oil remain in the subsurface despite the remediation efforts. Simple monitoring methods such as measuring field water-quality properties provided an inexpensive approach to evaluating the effects of the remediation. Rapid downgradient migration of the remediation plume likely was due to increased lateral advective flow caused by disposal of water in the infiltration gallery. The anoxic plume persisted beneath parts of the natural attenuation plume at least through July 2009, which was 5.5 years after the remediation ended. Although the remediation plume was expanded, laboratory analyses of water samples collected from wells indicate that the associated benzene, toluene, ethylbenzene, and xylene were fully degraded by 2007 , which was 3.5 years after the remediation ended. The lack of benzene, toluene, ethylbenzene, and xylene does not preclude the possibility of other nonvolatile dissolved organic carbon compounds being present in the remediation plume in addition to degradation products. Results similar to those previously mentioned would be expected at crude-oil spill sites with a similar hydrogeologic and climatic setting.

\section{References Cited}

Abdul, A.S., 1992, A new pumping strategy for petroleum product recovery from contaminated hydrogeologic systems - Laboratory and field evaluations: Ground Water Monitoring Review, v. 12, no. 1, p. 105-114. [Also available at https://doi.org/10.1111/j.1745-6592.1992.tb00415.x.]

Abdul, A.S., Kia, S.F., and Gibson, T.L., 1989, Limitations of monitoring wells for the detection and quantification of petroleum products in soils and aquifers: Ground Water Monitoring Review, v. 9, no. 2, p. 90-99. [Also available at https://doi.org/10.1111/j.1745-6592.1989.tb01144.x.]

American Petroleum Institute, 2003, Answers to frequently asked questions about managing risk at LNAPL sites: API Soil and Groundwater Research Bulletin Number 18, 24 p.

American Petroleum Institute, 2004, API Interactive LNAPL Guide - Version 2.0 - User guide for data retrieval: API Publication no. 4731.
Amos, R.T., Bekins, B.A., Cozzarelli, I.M., Voytek, M.A., Kirshtein, J.D., Jones, E.J.P., and Blowes, D.W., 2012, Evidence for iron-mediated anaerobic methane oxidation in a crude oil contaminated aquifer: Geobiology, v. 10, no. 6, p. 506-517. [Also available at https://doi.org/10.1111/ j.1472-4669.2012.00341.x.]

Amos, R.T., Mayer, K.U., Bekins, B.A., Delin, G.N., and Williams, R.L., 2005, Use of dissolved and vapor-phase gases to investigate methanogenic degradation of petroleum hydrocarbon contamination in the subsurface: Water Resources Research, v. 41, no. 2, art. W02001, 15 p. [Also available at https://doi.org/10.1029/2004WR003433.]

Barlow, P.M., and Moench, A.F., 1999, WTAQ—A computer program for calculating drawdowns and estimating hydraulic properties for confined and water-table aquifers: U.S. Geological Survey Water-Resources Investigations Report 99-4225, $74 \mathrm{p}$.

Bekins, B.A., Cozzarelli, I.M., Erickson, M.L., Steenson, R.A., and Thorn, K.A., 2016, Crude oil metabolites in groundwater at two spill sites: Ground Water, v. 54, no. 5, p. 681-691. [Also available at https://doi.org/10.1111/ gwat.12419.]

Bekins, B.A., Godsy, E.M., and Warren, E., 1999, Distribution of microbial physiologic types in an aquifer contaminated by crude oil: Microbial Ecology, v. 37, no. 4, p. 263-275. [Also available at https://doi.org/10.1007/s002489900149.]

Bekins, B.A., Hostettler, F.D., Herkelrath, W.N., Delin, G.N., Warren, E., and Essaid, H.I., 2005, Progression of methanogenic degradation of crude oil in the subsurface: Environmental Geoscience, v. 12, no. 2, p. 139-152. [Also available at https://doi.org/10.1306/eg.11160404036.]

Bennett, P.C., Siegel, D.E., Baedecker, M.J., and Hult, M.F., 1993, Crude oil in a shallow sand and gravel aquifer-I. Hydrogeology and inorganic geochemistry: Applied Geochemistry, v. 8, no. 6, p. 529-549. [Also available at https://doi.org/10.1016/0883-2927(93)90012-6.]

Caicedo, N.O.L., Neto, A.C.B., Finotti, A., and Melo, C.L., 2003, Evaluation of volume and performance of a free phase recovery system in an oil spill-Case study of an accident in Araucaria, Brazil, in Proceedings of the 2003 International Oil Spill Conference, April 8-10, 2003, Vancouver, Canada: Washington, D.C., American Petroleum Institute, p. 1021-1025.

Chaplin, B.P., Delin, G.N., Baker, R.J., and Lahvis, M.A., 2002, Long-term evolution of biodegradation and volatilization rates in a crude oil-contaminated aquifer: Bioremediation Journal, v. 6, no. 3, p. 237-255. [Also available at https://doi.org/10.1080/10889860290777594.]

Charbeneau, R.J., 2000, Groundwater hydraulics and pollutant transport: Englewood Cliffs, Prentice Hall, 593 p. 
Charbeneau, R.J., 2003, Models for design of free-product recovery systems for petroleum hydrocarbon liquids: Washington, D.C., American Petroleum Institute, API Publication no. $4729,70 \mathrm{p}$.

Charbeneau, R.J., 2007, LNAPL distribution and recovery model (LDRM): Washington, D.C., American Petroleum Institute, API Publication no. 4760, 68 p.

Charbeneau, R.J., Johns, R.T., Lake, L.W., and McAdams, M.J., III, 1999, Free-product recovery of petroleum hydrocarbon liquid: Washington, D.C., American Petroleum Institute, API Publication no. 4682, 173 p.

Cozzarelli, I.M., Bekins, B.A., Eganhouse, R.P., Warren, E., and Essaid, H.I., 2010, In situ measurements of volatile aromatic hydrocarbon biodegradation rates in groundwater: Journal of Contaminant Hydrology, v. 111, no. 1-4, p. 48-64. [Also available at https://doi.org/10.1016/ j.jconhyd.2009.12.001.]

Delin, G.N., Essaid, H.I., Cozzarelli, I.M., Lahvis, M.H., and Bekins, B.A., 1998, Ground water contamination by crude oil near Bemidji, Minnesota: U.S. Geological Survey Fact Sheet 084-98, 4 p. [Also available at https://doi.org/ 10.3133/fs08498.]

Delin, G.N., and Herkelrath, W.N., 1999, Long-term monitoring of unsaturated-zone properties to estimate recharge at the Bemidji crude-oil spill site, in Morganwalp, D.W., and Buxton, H.T., eds., U.S. Geological Survey Toxic Substances Hydrology Program-Proceedings of the Technical Meeting, Charleston, South Carolina, March 8-12, 1999-Volume 3 of 3-Subsurface Contamination From Point Sources: U.S. Geological Survey Water-Resources Investigations Report 99-4018C, p. $143-152$.

Delin, G.N., and Herkelrath, W.N., 2005, Use of soil moisture probes to estimate ground water recharge at an oil spill site: Journal of the American Water Resources Association, v. 41, no. 6, p. 1259-1277. [Also available at https://doi.org/ 10.1111/j.1752-1688.2005.tb03799.x.]

Delin, G.N., and Herkelrath, W.N., 2014, Effects of a dualpump crude-oil recovery system, Bemidji, Minnesota, USA: Ground Water Monitoring and Remediation, v. 34, no. 1, p. 57-67. [Also available at https://doi.org/10.1111/ gwmr.12040.]

Dillard, L.A., Essaid, H.I., and Herkelrath, W.N., 1997, Multiphase flow modeling of a crude-oil spill site with a bimodal permeability distribution: Water Resources Research, v. 33, no. 7, p. 1617-1632. [Also available at https://doi.org/10.1029/97WR00857.]
Dullien, F.A.L., 1992, Porous media fluid transport and pore structure 2nd ed.: San Diego, Calif., Academic Press, 574 p.

Eganhouse, R.P., Baedecker, M.J., Cozzarelli, I.M., Aiken, G.R., Thorn, K.A., and Dorsey, T.F., 1993, Crude oil in a shallow sand and gravel aquifer-II. Organic geochemistry: Applied Geochemistry, v. 8, no. 6, p. 551-567. [Also available at https://doi.org/10.1016/0883-2927(93)90013-7.]

Enbridge Energy, 2008, Project summary and water quality monitoring program, Pinewood, Minnesota (MP 926.53): Superior, Wis., Natural Resources Engineering Co., 54 p.

Essaid, H.I., Bekins, B.A., Herkelrath, W.N., and Delin, G.N., 2011, Crude oil at the Bemidji site-25 years of monitoring, modeling, and understanding: Ground Water, v. 49, no. 5, p. 706-726. [Also available at https://doi.org/10.1111/ j.1745-6584.2009.00654.x.]

Essaid, H.I., Bekins, B.A., Godsy, E.M., Warren, E., Baedecker, M.J., and Cozzarelli, I.M., 1995, Simulation of aerobic and anaerobic biodegradation processes at a crude oil spill site: Water Resources Research, v. 31, no. 12, p. 3309-3327. [Also available at https://doi.org/10.1029/ 95WR02567.]

Essaid, H.I., Cozzarelli, I.M., Eganhouse, R.P., Herkelrath, W.N., Bekins, B.A., and Delin, G.N., 2003, Inverse modeling of BTEX dissolution and biodegradation at the Bemidji, MN crude-oil spill site: Journal of Contaminant Hydrology, v. 67, no. 1-4, p. 269-299. [Also available at https://doi.org/ 10.1016/S0169-7722(03)00034-2.]

Farr, A.M., Houghtalen, R.J., and McWhorter, D.B., 1990, Volume estimation of light nonaqueous phase liquids in porous media: Ground Water, v. 28, no. 1, p. 48-56. [Also available at https://doi.org/10.1111/j.17456584.1990.tb02228.x.]

Franzi, D.A., 1988, Surficial and subsurface distribution of aquifer sediments at the Bemidji, Minnesota, research site, in Ragone, S.E., ed., U.S. Geological Survey Program on Toxic Waste - Ground-water contaminationProceedings of the second technical meeting, Cape Cod, Mass., October 21-25, 1985: U.S. Geological Survey Open-File Report 86-481, p. C5-C10. [Also available at https://doi.org/10.3133/ofr86481.]

Hampton, D.R., and Miller, P.D.G., 1988, Laboratory investigation of the relationship between actual and apparent product thickness in sands, in Proceedings of Petroleum Hydrocarbons and Organic Chemicals in Ground WaterPrevention, Detection and Restoration: Dublin, Ohio, National Water Well Association, p. 157-181. 
Herkelrath, W.N., 1999, Impacts of remediation at the Bemidji oil-spill site, in Morganwalp, D.W., and Buxton, H.T., eds., U.S. Geological Survey Toxic Substances Hydrology Program-Proceedings of the Technical Meeting, Charleston, South Carolina, March 8-12, 1999-Volume 3 of 3-Subsurface Contamination From Point Sources: U.S. Geological Survey Water-Resources Investigations Report 99-4018C, p. 159-167.

Hess, K.M., Herkelrath, W.N., and Essaid, H.I., 1992, Determination of subsurface fluid contents at a crude-oil spill site: Journal of Contaminant Hydrology, v. 10, no. 1, p. 75-96. [Also available at https://doi.org/10.1016/01697722(92)90044-F.]

Hult, M.F., 1984, Ground-water contamination by crude oil at the Bemidji, Minnesota, research site-An introduction, in Hult., M.F., ed., Ground-water contamination by crude oil at the Bemidji, Minnesota, research site-_-U.S. Geological Survey Toxic Waste-Ground-water contamination study: U.S. Geological Survey Water-Resources Investigations Report 84-4188, chap. A, p. 1-15.

Hult, M.F., and Grabbe, R.R., 1988, Distribution of gases and hydrocarbon vapors in the unsaturated zone, in Ragone, S.E., ed., U.S. Geological Survey Program on Toxic Waste-Ground-water Contamination-Proceedings of the second technical meeting, Cape Cod, Massachusetts, October 21-25, 1985: U.S. Geological Survey OpenFile Report 86-481, p. C21-C26. [Also available at https://doi.org/10.3133/ofr86481.]

Huntley, D., Hawk, R.N., and Corley, H.P., 1994a, Nonaqueous phase hydrocarbon in a fine-grained sandstone-1. Comparison between measured and predicted saturations and mobility: Ground Water, v. 32, no. 4, p. 626-634. [Also available at https://doi.org/10.1111/ j.1745-6584.1994.tb00898.x.]

Huntley, D., Wallace, J.W., and Hawk, R.N., 1994b, Nonaqueous phase hydrocarbon in a fine-grained sandstone-2. Effect of local sediment variability on the estimation of hydrocarbon volumes: Ground Water, v. 32, no. 5, p. 778-783. [Also available at https://doi.org/10.1111/ j.1745-6584.1994.tb00919.x.]

Kemblowski, M.W., and Chiang, C.Y., 1990, Hydrocarbon thickness fluctuations in monitoring wells: Ground Water, v. 28, no. 2, p. 244-252. [Also available at https://doi.org/ 10.1111/j.1745-6584.1990.tb02252.x.]

Landon, M.K., 1993, Investigation of mass loss based on evolution of composition and physical properties of spilled crude oil contaminating a shallow outwash aquifer: Minneapolis, University of Minnesota, master's thesis, $292 \mathrm{p}$.
Lenhard, R.J., and Parker, J.C., 1990, Estimation of free hydrocarbon volume from fluid levels in monitoring wells: Ground Water, v. 28, no. 1, p. 57-67. [Also available at https://doi.org/10.1111/j.1745-6584.1990.tb02229.x.]

Lundegard, P.D., and Mudford, B.S., 1998, LNAPL volume calculation-Parameter estimation by nonlinear regression of saturation profiles: Ground Water Monitoring and Remediation, v. 18, no. 3, p. 88-93. [Also available at https://doi.org/10.1111/j.1745-6592.1998.tb00732.x.]

Lundy, D.A., 2015, An investigation of the relationship between lateral spreading and mass depletion of an LNAPL body in contact with groundwater at the Bemidji, MN crude oil release site: Athens, University of Georgia, Ph.D. dissertation, $224 \mathrm{p}$.

Lundy, D.A., and Gogel, T., 1988, Capabilities and limitations of wells for detecting and monitoring liquid phase hydrocarbons - Proceedings of the Second National Outdoor Action Conference on Aquifer Restoration, Tulsa, Oklahoma: Ground Water Monitoring and Geophysical Methods, p. 343-362.

Marinelli, F., and Durnford, D.S., 1996, LNAPL thickness in monitoring wells considering hysteresis and entrapment: Ground Water, v. 34, no. 3, p. 405-414. [Also available at https://doi.org/10.1111/j.1745-6584.1996.tb02021.x.]

Mercer, J.W., and Cohen, R.M., 1990, A review of immiscible fluids in the subsurface-Properties, models, characterization and remediation: Journal of Contaminant Hydrology, v. 6, no. 2, p. 107-163. [Also available at https://doi.org/ 10.1016/0169-7722(90)90043-G.]

Miller, R.T., 1984, Determination of hydraulic conductivity in three dimensions and its relation to dispersivity, in Hult., M.F., ed., Ground-water contamination by crude oil at the Bemidji, Minnesota, research site-U.S. Geological Survey Toxic Waste-Ground-water contamination study: U.S. Geological Survey Water-Resources Investigations Report 84-4188, chap. D, p. 49-63.

Murphy, F., and Herkelrath, W.N., 1996, A sample-freezing drive shoe for a wire line piston core sampler: Ground Water Monitoring and Remediation, v. 16, no. 3, p. 86-90. [Also available at https://doi.org/10.1111/j.17456592.1996.tb00143.x.]

National Research Council, 2000, Natural attenuation for ground-water remediation: Washington, D.C., National Academy Press, 288 p.

Natural Resources Engineering Company, 1998, Remedial investigation and corrective action design report milepost 926.53: Pinewood, Minnesota, Prepared for Lakehead Pipe Line Company, August 1998, 86 p. 
Natural Resources Engineering Company, 1999, Operations and maintenance manual, Pinewood (MP 926.53):

Pinewood, Minnesota, Prepared for Lakehead Pipe Line, March 1999, 30 p.

Natural Resources Engineering Company, 2003, Crude oil recovery system enhancement feasibility study, Pinewood (MP 926.53): Pinewood, Minnesota, Prepared for Enbridge Energy Limited Partnership, August 2003, 19 p.

Natural Resources Engineering Company, 2008, Project summary and water quality monitoring program, Pinewood, Minnesota (MP 926.53): Prepared for Enbridge Energy Limited Partnership, May 2008, 54 p.

Ng, G.H.C., Bekins, B.A., Cozzarelli, I.M., Baedecker, M.J., Bennett, P.C., and Amos, R.T., 2014, A mass balance approach to investigating geochemical controls on secondary water quality impacts at a crude oil spill site near Bemidji, MN: Journal of Contaminant Hydrology, v. 164, p. 1-15. [Also available at https://doi.org/10.1016/ j.jconhyd.2014.04.006.]

Pfannkuch, H.O., 1979, Interim report and recommendations on monitoring program for site M.P. 926.5: Report prepared for Lakehead Pipe Line Company, Inc., 12 p.

Testa, S.M., and Winegardner, D.L., 2000, Restoration of petroleum-contaminated aquifers 2 nd ed.: Chelsea, Mich., Lewis Publishers, $446 \mathrm{p}$.

Trench, C.J., 2003, The U.S. oil pipeline industry's safety performance: Allegro Energy Consulting, 42 p.
Trench, C.J., 2011, Ten years of progress-Pipeline performance tracking system 1999-2009: Allegro Energy Consulting, API Pipeline Conference 2011, San Antonio, Texas, April 12, 2011.

Trost, J.J., Krall, A.L., Baedecker, M.J., Cozzarelli, I.M., Herkelrath, W.N., Jaeschke, J.B., Delin, G.N., Berg, A.M., and Bekins, B.A., 2020, Data sets from the National Crude Oil Spill Fate and Natural Attenuation Research site near Bemidji, Minnesota, USA (ver. 3.0, April 2020): U.S. Geological Survey data release, accessed July 15, 2020, at https://doi.org/10.5066/P9FJ8I0P.

Trost, J.J., Krall, A.L., Jaeschke, J.B., Berg, A.M., and Bekins, B.A., 2018, Sampling site information, well construction details, and data dictionaries for data sets associated with the National Crude Oil Spill Fate and Natural Attenuation Site near Bemidji, Minnesota (ver. 3.0, April 2020): U.S. Geological Survey data release, accessed July 15, 2020, at https://doi.org/10.5066/F7736PDR.

U.S. Environmental Protection Agency, 2005, Cost and performance report for LNAPL characterization and remediation: Washington, D.C., U.S. Government Printing Office, U.S. Environmental Protection Agency Report EPA 542-R-05-016, $47 \mathrm{p}$.

U.S. Geological Survey, 2020, USGS water data for the Nation: U.S. Geological Survey National Water Information System database, accessed July 15, 2020, at https://doi.org/ 10.5066/F7P55KJN.

Warren, E., and Bekins, B.A., 2018, Relative contributions of microbial and infrastructure heat at a crude oilcontaminated site: Journal of Contaminant Hydrology, v. 211, p. 94-103. [Also available at https://doi.org/10.1016/ j.jconhyd.2018.03.011.] 


\section{Appendix 1}


Table 1.1. U.S. Geological Survey site identification number, well type, screen elevation, and screen depth below land surface for wells used in this study.

[well type, purpose or use of well; USGS, U.S. Geological Survey; NWIS, National Water Information System; I.D., identifier; m, meter; NAVD 88, North American Vertical Datum of 1988]

\begin{tabular}{|c|c|c|c|c|}
\hline $\begin{array}{l}\text { Local well } \\
\text { number }\end{array}$ & Well type & USGS NWIS site I.D. & $\begin{array}{l}\text { Screen elevation } \\
\text { (m above NAVD 88) }\end{array}$ & $\begin{array}{c}\text { Screen depth below land } \\
\text { surface }(\mathrm{m})\end{array}$ \\
\hline $301 \mathrm{~A}$ & Water and oil & 473426095052526 & 422.79 & 6.04 \\
\hline $310 \mathrm{~A}$ & Water & 473422095053401 & 422.96 & 8.47 \\
\hline 312 & Water and oil & 473419095052301 & 422.71 & 1.55 \\
\hline 315 & Water and oil & 473419095052530 & 423.16 & 5.14 \\
\hline 421 & Water and oil & 473420095052610 & 420.81 & 7.84 \\
\hline 423 & Water and oil & 473420095052402 & 421.25 & 7.64 \\
\hline 528 & Water & 473420095051916 & 421.47 & 10.71 \\
\hline $533 \mathrm{D}$ & Water and oil & 473420095052321 & 423.12 & 8.54 \\
\hline $954 \mathrm{~A}$ & Water & 473421095051603 & 421.24 & 11.43 \\
\hline $955 \mathrm{~A}$ & Water & 473421095051501 & 421.60 & 11.53 \\
\hline 958 & Water and oil & 473421095052501 & 422.42 & 3.91 \\
\hline 980 & Water and oil & 473421095052305 & 422.70 & 1.76 \\
\hline $301 \mathrm{G}-01$ & Vapor & 473426095052609 & 423.02 & 7.0 \\
\hline $301 \mathrm{G}-02$ & Vapor & 473426095052615 & 424.02 & 6.0 \\
\hline $301 \mathrm{G}-03$ & Vapor & 473426095052616 & 425.02 & 5.0 \\
\hline $301 \mathrm{G}-04$ & Vapor & 473426095052617 & 426.02 & 4.0 \\
\hline $301 G-05$ & Vapor & 473426095052618 & 427.02 & 3.0 \\
\hline $301 \mathrm{G}-06$ & Vapor & 473426095052619 & 428.02 & 2.0 \\
\hline $301 \mathrm{G}-07$ & Vapor & 473426095052620 & 429.02 & 1.0 \\
\hline $301 \mathrm{G}-08$ & Vapor & 473426095052621 & 429.52 & 0.5 \\
\hline $518 \mathrm{G}-01$ & Vapor & 473426095052311 & 426.01 & 6.5 \\
\hline $518 \mathrm{G}-02$ & Vapor & 473426095052319 & 427.01 & 5.5 \\
\hline $518 \mathrm{G}-03$ & Vapor & 473426095052320 & 428.01 & 4.5 \\
\hline $518 \mathrm{G}-04$ & Vapor & 473426095052322 & 429.01 & 3.5 \\
\hline $518 \mathrm{G}-05$ & Vapor & 473426095052323 & 430.01 & 2.5 \\
\hline $518 \mathrm{G}-06$ & Vapor & 473426095052324 & 431.01 & 1.5 \\
\hline $518 \mathrm{G}-07$ & Vapor & 473426095052337 & 432.01 & 0.5 \\
\hline $530 \mathrm{G}-01$ & Vapor & 473427095052208 & 426.28 & 6.5 \\
\hline $530 \mathrm{G}-02$ & Vapor & 473427095052210 & 427.28 & 5.5 \\
\hline $530 \mathrm{G}-03$ & Vapor & 473427095052211 & 428.28 & 4.5 \\
\hline $530 \mathrm{G}-04$ & Vapor & 473427095052212 & 429.28 & 3.5 \\
\hline $530 \mathrm{G}-05$ & Vapor & 473427095052213 & 430.28 & 2.5 \\
\hline $530 \mathrm{G}-06$ & Vapor & 473427095052214 & 431.28 & 1.5 \\
\hline $530 \mathrm{G}-07$ & Vapor & 473427095052215 & 432.28 & 0.5 \\
\hline $531 \mathrm{G}-01$ & Vapor & 473426095052312 & 425.88 & 6.5 \\
\hline $531 \mathrm{G}-02$ & Vapor & 473426095052325 & 426.88 & 5.5 \\
\hline $531 \mathrm{G}-03$ & Vapor & 473426095052326 & 427.88 & 4.5 \\
\hline $531 \mathrm{G}-04$ & Vapor & 473426095052327 & 428.88 & 3.5 \\
\hline $531 \mathrm{G}-05$ & Vapor & 473426095052328 & 429.88 & 2.5 \\
\hline $531 \mathrm{G}-06$ & Vapor & 473426095052329 & 430.88 & 1.5 \\
\hline $531 \mathrm{G}-07$ & Vapor & 473426095052330 & 431.88 & 0.5 \\
\hline
\end{tabular}


Table 1.1. U.S. Geological Survey site identification number, well type, screen elevation, and screen depth below land surface for wells used in this study.-Continued

[well type, purpose or use of well; USGS, U.S. Geological Survey; NWIS, National Water Information System; I.D., identifier; m, meter; NAVD 88, North American Vertical Datum of 1988]

\begin{tabular}{|c|c|c|c|c|}
\hline $\begin{array}{l}\text { Local well } \\
\text { number }\end{array}$ & Well type & USGS NWIS site I.D. & $\begin{array}{l}\text { Screen elevation } \\
\text { (m above NAVD 88) }\end{array}$ & $\begin{array}{c}\text { Screen depth below land } \\
\text { surface }(\mathrm{m})\end{array}$ \\
\hline $532 \mathrm{G}-01$ & Vapor & 473426095052315 & 425.84 & 6.5 \\
\hline $532 \mathrm{G}-02$ & Vapor & 473426095052331 & 426.84 & 5.5 \\
\hline $532 \mathrm{G}-03$ & Vapor & 473426095052332 & 427.84 & 4.5 \\
\hline $532 \mathrm{G}-04$ & Vapor & 473426095052333 & 428.84 & 3.5 \\
\hline $532 \mathrm{G}-05$ & Vapor & 473426095052334 & 429.84 & 2.5 \\
\hline $532 \mathrm{G}-06$ & Vapor & 473426095052335 & 430.84 & 1.5 \\
\hline $532 \mathrm{G}-07$ & Vapor & 473426095052336 & 431.84 & 0.5 \\
\hline $533 \mathrm{G}-01$ & Vapor & 473426095052413 & 425.87 & 6.5 \\
\hline $533 \mathrm{G}-02$ & Vapor & 473426095052420 & 426.87 & 5.5 \\
\hline $533 \mathrm{G}-03$ & Vapor & 473426095052421 & 427.87 & 4.5 \\
\hline $533 \mathrm{G}-04$ & Vapor & 473426095052448 & 428.87 & 3.5 \\
\hline $533 \mathrm{G}-05$ & Vapor & 473426095052449 & 429.87 & 2.5 \\
\hline $533 \mathrm{G}-06$ & Vapor & 473426095052450 & 430.87 & 1.5 \\
\hline $533 \mathrm{G}-07$ & Vapor & 473426095052451 & 431.87 & 0.5 \\
\hline $534 \mathrm{G}-01$ & Vapor & 473426095052452 & 425.64 & 6.5 \\
\hline $534 \mathrm{G}-02$ & Vapor & 473426095052453 & 426.64 & 5.5 \\
\hline $534 \mathrm{G}-03$ & Vapor & 473426095052454 & 427.64 & 4.5 \\
\hline $534 \mathrm{G}-04$ & Vapor & 473426095052455 & 428.64 & 3.5 \\
\hline $534 \mathrm{G}-05$ & Vapor & 473426095052456 & 429.64 & 2.5 \\
\hline $534 \mathrm{G}-06$ & Vapor & 473426095052457 & 430.64 & 1.5 \\
\hline $534 \mathrm{G}-07$ & Vapor & 473426095052458 & 431.64 & 0.5 \\
\hline $601 \mathrm{G}-01$ & Vapor & 473426095052502 & 425.28 & 6.5 \\
\hline $601 \mathrm{G}-02$ & Vapor & 473426095052513 & 426.28 & 5.5 \\
\hline $601 \mathrm{G}-03$ & Vapor & 473426095052514 & 427.28 & 4.5 \\
\hline $601 \mathrm{G}-04$ & Vapor & 473426095052515 & 428.28 & 3.5 \\
\hline $601 \mathrm{G}-05$ & Vapor & 473426095052516 & 429.28 & 2.5 \\
\hline $601 \mathrm{G}-06$ & Vapor & 473426095052517 & 430.28 & 1.5 \\
\hline $601 \mathrm{G}-07$ & Vapor & 473426095052518 & 431.28 & 0.5 \\
\hline $604 \mathrm{G}-01$ & Vapor & 473425095052701 & 423.33 & 6.5 \\
\hline $604 \mathrm{G}-02$ & Vapor & 473425095052723 & 424.33 & 5.5 \\
\hline $604 \mathrm{G}-03$ & Vapor & 473425095052724 & 425.33 & 4.5 \\
\hline $604 \mathrm{G}-04$ & Vapor & 473425095052725 & 426.33 & 3.5 \\
\hline $604 \mathrm{G}-05$ & Vapor & 473425095052726 & 427.33 & 2.5 \\
\hline $604 \mathrm{G}-06$ & Vapor & 473425095052727 & 428.33 & 1.5 \\
\hline $604 \mathrm{G}-07$ & Vapor & 473425095052728 & 429.33 & 0.5 \\
\hline $9101 \mathrm{G}-01$ & Vapor & 473426095052417 & 425.47 & 6.5 \\
\hline $9101 \mathrm{G}-02$ & Vapor & 473426095052431 & 426.47 & 5.5 \\
\hline $9101 \mathrm{G}-03$ & Vapor & 473426095052432 & 427.47 & 4.5 \\
\hline 9101G-04 & Vapor & 473426095052433 & 428.47 & 3.5 \\
\hline $9101 \mathrm{G}-05$ & Vapor & 473426095052434 & 429.47 & 2.5 \\
\hline $9101 \mathrm{G}-06$ & Vapor & 473426095052435 & 430.47 & 1.5 \\
\hline
\end{tabular}


Table 1.1. U.S. Geological Survey site identification number, well type, screen elevation, and screen depth below land surface for wells used in this study.-Continued

[well type, purpose or use of well; USGS, U.S. Geological Survey; NWIS, National Water Information System; I.D., identifier; m, meter; NAVD 88, North American Vertical Datum of 1988]

\begin{tabular}{|c|c|c|c|c|}
\hline $\begin{array}{l}\text { Local well } \\
\text { number }\end{array}$ & Well type & USGS NWIS site I.D. & $\begin{array}{l}\text { Screen elevation } \\
\text { (m above NAVD 88) }\end{array}$ & $\begin{array}{c}\text { Screen depth below land } \\
\text { surface }(\mathrm{m})\end{array}$ \\
\hline $9101 \mathrm{G}-07$ & Vapor & 473426095052436 & 430.97 & 1.0 \\
\hline $9101 \mathrm{G}-08$ & Vapor & 473426095052437 & 431.47 & 0.5 \\
\hline 9101G-09 & Vapor & 473426095052438 & 431.97 & 0.2 \\
\hline $9103 \mathrm{G}-01$ & Vapor & 473426095052418 & 425.90 & 6.5 \\
\hline $9103 \mathrm{G}-02$ & Vapor & 473426095052439 & 426.90 & 5.5 \\
\hline $9103 \mathrm{G}-03$ & Vapor & 473426095052440 & 427.90 & 4.5 \\
\hline $9103 \mathrm{G}-04$ & Vapor & 473426095052441 & 428.90 & 3.5 \\
\hline $9103 \mathrm{G}-05$ & Vapor & 473426095052442 & 429.90 & 2.5 \\
\hline $9103 \mathrm{G}-06$ & Vapor & 473426095052443 & 430.90 & 1.5 \\
\hline $9103 \mathrm{G}-07$ & Vapor & 473426095052444 & 431.40 & 1.0 \\
\hline 9103G-08 & Vapor & 473426095052445 & 431.90 & 0.5 \\
\hline 9014G-01 & Vapor & 473426095052504 & 423.48 & 7.93 \\
\hline 9014G-02 & Vapor & 473426095052519 & 423.78 & 7.63 \\
\hline 9014G-03 & Vapor & 473426095052520 & 424.08 & 7.33 \\
\hline $9014 \mathrm{G}-04$ & Vapor & 473426095052521 & 424.48 & 6.93 \\
\hline 9014G-05 & Vapor & 473426095052522 & 425.48 & 5.93 \\
\hline $9014 \mathrm{G}-06$ & Vapor & 473426095052523 & 426.48 & 4.93 \\
\hline 9014G-07 & Vapor & 473426095052524 & 427.48 & 3.93 \\
\hline 9014G-08 & Vapor & 473426095052525 & 428.48 & 2.93 \\
\hline $9015 \mathrm{G}-01$ & Vapor & 473425095052506 & 424.91 & 6.5 \\
\hline $9015 \mathrm{G}-02$ & Vapor & 473425095052522 & 425.91 & 5.5 \\
\hline $9015 \mathrm{G}-03$ & Vapor & 473425095052524 & 426.91 & 4.5 \\
\hline $9015 \mathrm{G}-04$ & Vapor & 473425095052525 & 427.91 & 3.5 \\
\hline $9015 \mathrm{G}-05$ & Vapor & 473425095052526 & 428.91 & 2.5 \\
\hline $9015 \mathrm{G}-06$ & Vapor & 473425095052527 & 429.41 & 2.0 \\
\hline $9015 \mathrm{G}-07$ & Vapor & 473425095052528 & 429.91 & 1.5 \\
\hline $9015 \mathrm{G}-08$ & Vapor & 473425095052529 & 430.41 & 1.0 \\
\hline $9016 \mathrm{G}-01$ & Vapor & 473425095052613 & 423.61 & 6.0 \\
\hline $9016 \mathrm{G}-02$ & Vapor & 473425095052616 & 424.61 & 5.0 \\
\hline $9016 \mathrm{G}-03$ & Vapor & 473425095052617 & 425.61 & 4.0 \\
\hline 9016G-04 & Vapor & 473425095052618 & 426.61 & 3.0 \\
\hline $9016 \mathrm{G}-05$ & Vapor & 473425095052619 & 427.61 & 2.0 \\
\hline $9016 \mathrm{G}-06$ & Vapor & 473425095052620 & 428.11 & 1.5 \\
\hline $9016 \mathrm{G}-07$ & Vapor & 473425095052621 & 428.61 & 1.0 \\
\hline $9016 \mathrm{G}-08$ & Vapor & 473425095052622 & 429.11 & 0.5 \\
\hline
\end{tabular}


Table 1.1. U.S. Geological Survey site identification number, well type, screen elevation, and screen depth below land surface for wells used in this study.-Continued

[well type, purpose or use of well; USGS, U.S. Geological Survey; NWIS, National Water Information System; I.D., identifier; m, meter; NAVD 88, North American Vertical Datum of 1988]

\begin{tabular}{llccc}
\hline $\begin{array}{c}\text { Local well } \\
\text { number }\end{array}$ & Well type & USGS NWIS site I.D. & $\begin{array}{c}\text { Screen elevation } \\
\text { (m above NAVD 88) }\end{array}$ & $\begin{array}{c}\text { Screen depth below land } \\
\text { surface (m) }\end{array}$ \\
\hline 9017G-01 & Vapor & 473425095052703 & 423.74 & 5.9 \\
$9017 \mathrm{G}-02$ & Vapor & 473425095052716 & 424.74 & 4.9 \\
$9017 \mathrm{G}-03$ & Vapor & 473425095052717 & 425.74 & 3.9 \\
$9017 \mathrm{G}-04$ & Vapor & 473425095052718 & 426.74 & 2.9 \\
$9017 \mathrm{G}-05$ & Vapor & 473425095052719 & 427.24 & 2.4 \\
$9017 \mathrm{G}-06$ & Vapor & 473425095052720 & 427.74 & 1.9 \\
$9017 \mathrm{G}-07$ & Vapor & 473425095052721 & 428.74 & 0.9 \\
$9017 \mathrm{G}-08$ & Vapor & 473425095052722 & 429.74 & 0.4 \\
\hline
\end{tabular}



For more information about this publication, contact: Director, USGS Upper Midwest Water Science Center 2280 Woodale Drive

Mounds View, MN 55112

763-783-3100

For additional information, visit: https://www.usgs.gov/centers/ umid-water

Publishing support provided by the

Rolla Publishing Service Center 


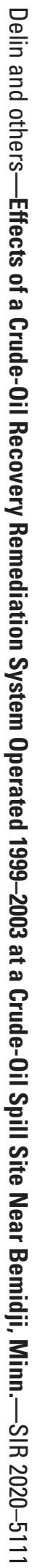

